\title{
O Mundo Do Trabalho Em Tempos De Pandemia No Brasil: O Incremento Da Precarização Da Força Laboral
}

\author{
Otávio Bruno da Silva Ferreira* \\ Centro Universitário do Estado do Pará, Programa de Pós-Graduação em Direito, Belém-PA, Brasil.
} (iD https://orcid.org/0000-0002-4605-2899

\author{
Suzy Elizabeth Cavalcante Koury** \\ Centro Universitário do Pará, Programa de Pós-Graduação Stricto Sensu em Direito, Belém-PA, Brasil.
}

Felipe Guimarães de Oliveira***

Centro Universitário do Pará, Programa de Pós-Graduação Stricto Sensu em Direito, Belém-PA, Brasil.

(iD) https://orcid.org/0000-0002-7917-7487

Resumo: A pandemia do coronavírus provocou diversas e profundas alterações no mundo do trabalho. Neste estudo, buscou-se analisar se as medidas legislativas adotadas pelo governo brasileiro têm sido eficientes para combater o desemprego e a precarização do trabalho durante a pandemia. Apontou-se, como objetivo geral, identificar se as medidas legislativas são eficientes para a redução do desemprego. Para tanto, analisou-se o contexto de implementação do neoliberalismo em relação ao mundo do trabalho e às suas consequências, apresentou-se o rol dos principais diplomas legislativos editados durante a pandemia e, ao fim, respondeu-se que, a partir do exame de dados oficiais, a regulação da relação laboral ocorreu sob o viés do empresariado, com o aprofundamento da precarização das relações laborais, revelando-se como não eficaz para combater o desemprego durante a pandemia. Metodologicamente, a pesquisa é qualitativa, exploratória, com levantamento bibliográfico e documental. Divide-se em seções que apresentam um breve panorama sobre a influência do capitalismo no mundo do trabalho, a emergência de novos marcos regulatórios na seara trabalhista e, ao fim, o exame dos reflexos do avanço das políticas neoliberais no esfacelamento da tutela trabalhista, com o aumento dos índices de desemprego, de flexibilização e de precarização.

Palavras-chave: COVID-19; Desemprego; Medidas Legislativas; Neoliberalismo. Precarização.

\footnotetext{
* Mestre em Direito, Políticas Públicas e Desenvolvimento Regional, pelo CESUPA. Professor no curso de graduação em Direito do Centro Universitário FIBRA. Juiz do Trabalho Substituto do Tribunal Regional do Trabalho da 8a Região. E-mail: otavio.ferreira@trt8.jus.br

** Doutora em Direito pela Universidade Federal de Minas Gerais. Docente permanente do Programa de Pós-Graduação Stricto Sensu em Direito, Políticas Públicas e Desenvolvimento e do CESUPA. Desembargadora do Tribunal Regional do Trabalho da 8ª Região. E-mail: suzykoury@gmail.com

*** Doutorando em Direito pela Universidade Federal do Pará. Professor do CESUPA. E-mail: otavio.ferreira@trt8.jus.br
}

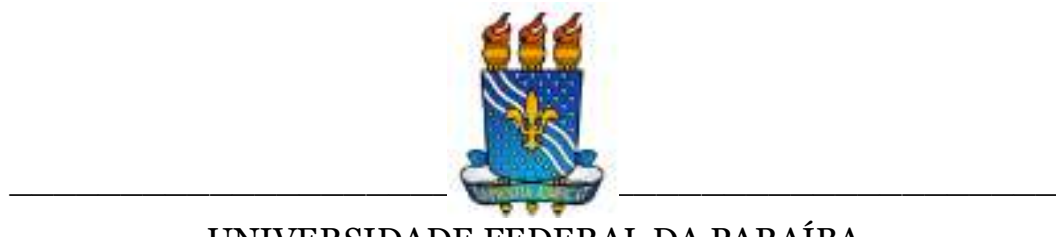

UNIVERSIDADE FEDERAL DA PARAÍBA

Programa de Pós-Graduação em Ciências Jurídicas 


\title{
O Mundo Do Trabalho Em Tempos De Pandemia No Brasil: O Incremento Da Precarização Da Força Laboral
}

\author{
Otávio Bruno da Silva Ferreira
}

Suzy Elizabeth Cavalcante Koury

Felipe Guimarães de Oliveira

\section{INTRODUÇÃO}

O pensamento neoliberal evoluiu para uma valorização excessiva do ideal de livre mercado e concorrência, e, de certa forma, para uma redução da figura do Estado regulador como instrumento de coibição de condutas e de repressão ao abuso do poder econômico pelos detentores do capital.

Essa perspectiva tem abalado o mundo do trabalho com uma série de transformações negativas e supressivas de direitos conquistados ao longo dos séculos XX e XXI pela classe trabalhadora, que vêm sendo afastados ou relativizados por intermédio de medidas legislativas de flexibilização e de precarização, formatando uma realidade de empobrecimento generalizado da classe trabalhadora.

Fundamental, no entanto, é entender que esse cenário, provocado pela flexibilização e pela desestruturação da tutela protetiva ao trabalhador vulnerável, expõe uma lógica de atuação do Estado, omisso e subordinado, que se posiciona, com frequência, pela defesa do capital, e não pela ideia de justiça social, consagrada pela ordem econômica da Constituição Federal de 1988, em seu artigo 170 (BRASIL, 1988). 
Essa lógica revelou-se muito claramente nesses tempos da pandemia do COVID-19, no Brasil, no primeiro semestre de 2020, em que as medidas adotadas pelo governo e outras por ele sinalizadas se direcionam a uma maior redução de direitos dos trabalhadores precários e hipervulneráveis, entendidos como tais os que combinam baixa remuneração, falta de representação sindical e exclusão do sistema público de proteção do trabalho.

Nesse contexto, o artigo propõe uma análise sobre os reflexos do neoliberalismo no mundo do trabalho. Como questionamento central, o texto indaga: as medidas legislativas adotadas pelo governo brasileiro têm sido eficientes para combater o desemprego e a precarização do trabalho durante a pandemia do COVID-19?

Aponta-se como objetivo geral do presente estudo identificar se as medidas legislativas aprovadas durante a pandemia são eficazes para a redução do desemprego ou se estão em consonância com a ideia de precarização das relações de trabalho, tema que vem ocupando espaço na agenda legislativa na última década, com destaque especial para a Lei no . 13.467/2017 (BRASIL, 2017), conhecida como Lei da Reforma Trabalhista.

Para alcançar o objetivo acima, elencam-se, como objetivos específicos: a) analisar o contexto de implementação do neoliberalismo em relação ao mundo do trabalho e às suas consequências; b) expor os principais diplomas legislativos por meio dos quais o Brasil buscou regular o mundo do trabalho nos tempos de pandemia e c) por fim, responder o questionamento principal, por intermédio do exame dos dados relativos ao emprego e à economia informal durante a crise pandêmica.

A partir desse problema de pesquisa, as análises deste estudo, metodologicamente, são de abordagem qualitativa e, quanto aos objetivos, exploratórias. Como procedimentos, tem-se o levantamento bibliográfico e documental, com especial enfoque às medidas legislativas adotadas durante o estado de calamidade pública, reconhecido pelo Decreto Legislativo no 6/2020 (BRASIL, 2020), 
pesquisas do IBGE e do DIEESE, entre outras fontes primárias e secundárias.

Além da introdução e das considerações finais, o texto está estruturado em mais três seções. Na primeira delas, far-se-á uma abordagem da evolução do capitalismo em relação ao mundo do trabalho até a introdução do neoliberalismo, caracterizado pela defesa do empreendedorismo autônomo, da flexibilização e da redução de direitos trabalhistas. Na segunda, discorrer-se-á sobre os principais diplomas legislativos por meio dos quais o Brasil buscou regular o mundo do trabalho nos tempos de pandemia, com o apontamento das regras fundamentais de cada um deles, os instrumentos colocados à disposição do empregador e o exame, quando cabível, da compatibilidade de conteúdo com as normas e os princípios do Direito do Trabalho. Por fim, na última seção, analisar-se-ão os dados relativos ao emprego e à economia informal durante a crise pandêmica, com o propósito de responder ao questionamento que norteia a pesquisa, o que é feito especificamente nas considerações finais.

Entende-se que ainda é prematuro indicar todas as consequências decorrentes da pandemia e dos marcos regulatórios no mercado de trabalho. Todavia, o presente estudo apresenta-se como contribuição para a discussão sobre os rumos adotados pelo governo para a regulação do mundo do trabalho, com a crítica necessária e o apontamento da necessidade de correção urgente do caminho, com o objetivo de evitar o aviltamento do ser humano.

\section{O NEOLIBERALISMO E O MUNDO DO TRABALHO}

A estruturação do capitalismo e a constituição de relações capitalistas de produção deu-se quando da Primeira Revolução Industrial (PRONI, 1997), a partir da qual a humanidade experimentou diferentes contextos sociais, políticos e econômicos, que 
O Mundo Do Trabalho Em Tempos De Pandemia No Brasil: 0 Incremento Da...

revelam a construção histórica e relativa das regras estabelecidas para a sua regulação.

Garcia e Moreira (2020, p. 860) explicam que o desenvolvimento das forças produtivas possibilitou a formação de novas e sucessivas divisões do trabalho até permitir que não produtores (pessoas, empresas, classes ou o Estado, por exemplo) pudessem se apropriar privadamente de uma parcela do que era executado pelo conjunto dos produtores diretos, caracterizando a exploração do trabalho alheio.

Neste estudo, interessa-nos discutir os padrões de regulação social do trabalho dos primórdios do capitalismo concorrencial do século XIX, especialmente na Inglaterra, marcado pela desconstrução de direitos sociais para proporcionar a consolidação do assalariamento e pela intensa exploração do trabalho humano.

Naquele contexto, o papel do Estado era garantir as condições necessárias aos industriais, inclusive por meio de regras que impuseram a migração dos camponeses às cidades inglesas e os impeliram a aceitar o trabalho nas fábricas, em troca de salários miseráveis, dada a criminalização do que se chamava de vagabundagem, caracterizada pela falta de ocupação. Como destaca Polanyi (2012, parte 2), ao analisar a New Poor Law, na Inglaterra, a criação de um mercado de trabalho exigiu um drástico aumento dos poderes repressivos do Estado, revelando o falso mito da autorregulação do mercado.

No século XX, após as Grandes Guerras Mundiais e a Grande Depressão, com o crash da Bolsa de Nova Iorque (EUA), em 1929, evoluiu-se para a regulação pública do trabalho, caracterizada pelo advento do assalariamento. Esse período coincidiu, em grande parte, com o que se costuma chamar de "Anos Dourados" do capitalismo (HOBSBAWM, 1995), que tiveram início em 1945, com o final da Segunda Guerra Mundial, até cerca de 1970, quando ocorreu a Crise do Petróleo, em que se experimentou um gradativo abandono da regulação do Estado sobre o capital que, também ele, já se 
transformara, com a globalização financeira.

As grandes transformações tecnológicas ocorridas nos anos 90 mudaram, sem qualquer dúvida, a estrutura do mercado de trabalho, tendo, como principais consequências, segundo Faria (2010), o aumento do "fosso" entre ganhos das várias categorias de empregados e a condenação ao desemprego crônico dos menos qualificados, proporcionando tanto o enfraquecimento das demandas operárias e de seus sindicatos, quanto o esvaziamento dos modelos sociais democratas de transformação social e política.

No que diz respeito ao trabalho, portanto, vive-se o neoliberalismo do século XXI e seu claro processo de desconstrução dos direitos trabalhistas, como uma resposta à crise econômica e ao desemprego, procedendo-se a alterações legislativas, reduzindo-se o papel da Justiça do Trabalho, dos sindicatos e do Ministério Público do Trabalho e se adequando o trabalho à dinâmica das empresas, de modo que o empresariado passe a controlar a contratação e a força de trabalho.

Defende-se a não intervenção do Estado no mercado e nas relações de trabalho, cada vez mais flexibilizadas e pautadas pela ideia do empreendedorismo individual, que transforma o trabalhador em seu próprio chefe e pela possibilidade de negociação direta entre empregado e empregador, sem a intermediação sindical e com a prevalência do negociado sobre o legislado.

A ideia de garantir liberdade no mercado está diretamente relacionada à supressão das regulamentações nacionais. Nesse sentido, Ferrer e Alves (2018, p. 4) afirmam que, quanto ao mundo do trabalho, é possível identificar a existência de política de flexibilização das relações trabalhistas, seguindo os ditames neoliberais, com a ideia de diminuir a atuação do Estado, tornando mais maleáveis as negociações entre as partes.

O cenário de subordinação do Estado levou Martínez Lazcano (2020, p. 3) a pontuar que é o ambiente ideal para a constituição de grupos privados como fatores reais de poder, paralelos ao Estado, e que o vão substituindo nas tarefas sociais relacionadas diretamente 
aos interesses do mercado, inclusive a ponto de transformar-se em um poder transnacional.

Houve a formação dos centros de poder econômico, com coordenação e relação de subordinação do Estado, o qual passa a realizar reformas estruturantes com o objetivo de atender aqueles interesses. Nessa conjuntura, observa-se a flexibilização de direitos trabalhistas, considerada como fundamental para resolver o problema do desemprego, resultando, então, em uma transição de um Estado provedor para um Estado facilitador da lógica do mercado e descomprometido com políticas sociais (DUPAS, 1998, p. 182).

Identifica-se a permanente ocupação e discussão sobre as relações de trabalho, as quais exercem centralidade dentro do modelo de subordinação capitalista. Por isso, Pereira (2020, p. 1004) enfatiza “que o capitalismo é, por excelência, o tipo de sociedade constituída pelo trabalho, com isso diferenciando-se de formações précapitalistas".

Garcia e Moreira (2020, p. 863) vão além e destacam que "sem trabalho e sem salário, para o capital, o ser humano sequer existe. Suas relações são bestializadas, como animais que agem por instinto de sobrevivência”, assertiva que demonstra a importância do trabalho para o modelo de produção capitalista. Por outro lado, criou-se, nas últimas décadas, a falsa impressão de que todos podem empreender e todos podem ser empreendedores, ignorando (ou não), uma gama de dificuldades inerentes a tal processo, como a formação técnicoprofissional do trabalhador e as condições financeiras para a realização de aportes de capital e de contratações, na grande maioria das vezes inexistentes na realidade brasileira.

Postone (2014, p. 31) apresenta uma situação que não pode ser ignorada ao se pretender compreender as formas de alteração do capitalismo contemporâneo, qual seja, a necessidade de substituir o ângulo de análise de uma crítica do capitalismo do ponto de vista do trabalho (ou seja, a crítica da exploração típica do marxismo tradicional, que, segundo o autor, limita-se a questões de distribuição) 
para uma crítica do trabalho no capitalismo (e como ele está ligado a uma forma abstrata de dominação social que é independente da dominação de classe).

A dominação abstrata é identificada a partir do momento em que o trabalhador não consegue sequer identificar a origem das ordens que cumpre. O modo de produção do trabalho, nessa fase capitalista, tornou-se invisível, transnacional, tecnológico, com uma nova morfologia que submete o trabalhador a um processo de dominação, dentro do invólucro de autonomia e que dificulta a formação do sentimento de classe, de coletivo.

E, no ambiente de crise, assinala Balmant Emerique (2020, p. 83), o regime de austeridade promovido pela política econômica contemporânea revela a ascensão de um capitalismo radical de raiz neoliberal, que se amparou em capitais e em modus operandi de países considerados emergentes, para tentar agenciar o desmantelamento do Estado social na Europa e, após, nos demais países, igualando rendimentos, condições de trabalho e estilos de vida (com os menos privilegiados).

Dentre as principais medidas de austeridade, destacam-se: a) a desregulamentação, com o avanço da precariedade no trabalho qualificado e não qualificado; b) a redução de garantias e salários pagos a contratados e a novos contratados e as mudanças na previdência social (por exemplo, o aumento da idade para aposentadoria); c) as privatizações das funções básicas do Estado; d) o engrandecimento do setor privado e f) a demonização do setor público (BALMANT EMERIQUE, 2020, p. 83).

Deve-se salientar, ainda, que os descaminhos da austeridade, propalados como a única saída para a crise, refletem-se perversamente sobre a sociedade e, especialmente, para os mais vulneráveis, trazendo de volta o fantasma da pobreza, após o seu recuo efetivo nos anos anteriores com as políticas de melhoria de ingresso (BALMANT EMERIQUE, 2020, p. 83).

Wood (2014) aponta, entretanto, que o Estado continua sendo indispensável, pois, o próprio fato de a globalização ter estendido os 
O Mundo Do Trabalho Em Tempos De Pandemia No Brasil: 0 Incremento Da...

poderes puramente econômicos muito além do alcance de qualquer Estado nacional, revela que o capital global exige muitos Estadosnações para executar as funções administrativas e coercitivas que sustentam o sistema de propriedade e oferecem o tipo de regularidade e previsibilidade, bem como a ordem legal que o capitalismo necessita.

No Brasil, o avanço do neoliberalismo aumentou a pressão por alterações legislativas com viés flexibilizador da legislação trabalhista, que redundou na promulgação da Lei ${ }^{0}$ 13.467/2017 (BRASIL, 2017), com a promessa de gerar empregos, proporcionar a retomada econômica, incentivar os investimentos, melhorar os indicadores de produtividade e de competitividade, reduzir a judicialização e estimular a livre negociação.

Logo após a sua entrada em vigor, que se deu em 11.11.2017, as evidências empíricas não corroboraram a relação entre a mudança legislativa e o aumento dos postos de trabalho, sendo verificada a deflação salarial, a redução de direitos sociais e a contenção do tamanho do Estado, claras consequências da política de austeridade (SILVA, S., 2018, p. 215).

Assim, sem que alcançasse os resultados a que se propusera, à exceção, talvez, da redução de demandas na Justiça do Trabalho, em virtude da possibilidade de se cobrar dos trabalhadores custas e honorários sucumbenciais na hipótese de insucesso da demanda, o país e o resto do mundo foram surpreendidos com a pandemia global do COVID-19, que exigiu uma atuação firme e, mais uma vez, impactou o mundo do trabalho.

No Brasil, no âmbito do trabalho, foram editadas diversas normas, todas revestidas de urgência, que permitem que se fale na existência de um marco regulatório próprio para os tempos de crise, que passamos a analisar. 


\section{A REGULAMENTAÇÃO DAS RELAÇÕES LABORAIS DURANTE A PANDEMIA}

Com a decretação do estado de calamidade pública, houve uma disruptura em diversos setores da sociedade, com a necessidade de adoção de mecanismos voltados à adequação dos cenários específicos a uma nova realidade. Tal situação alcançou, especialmente, as relações laborais, em face da tomada de medidas necessárias à prevenção de contaminação pelo novo coronavírus.

O resultado foi a edição de várias medidas provisórias, algumas convertidas em lei e outras que perderam a vigência por decurso do prazo, voltadas à flexibilização das relações laborais.

A importância do estudo sobre o marco regulatório é justificada em virtude do fato de que, em tempos de recessão, de crise, de contração financeira, sob agendas liberais ou conservadoras, as mudanças no conteúdo das normas trabalhistas por serem tão significativas, que já se recorre à expressão "Direito do Trabalho em Crise”, para designar o conjunto de institutos jurídicos aparentemente provisórios, mas que provocam marcas profundas na estrutura do ramo trabalhista, ainda após os períodos citados (SILVA S., 2020, p. 37).

No mesmo sentido, Valente, Fogaça e Silva (2018, p. 4) assinalam, com precisão, que o reformismo do Estado configura-se historicamente como uma estratégia propícia, em contextos de crise, no sentido de mudar parte do que está posto, para manter assegurado os pontos centrais dos interesses daqueles que ocupam o poder estatal, e/ou mantém representantes de seus interesses no governo.

Para fins deste estudo, analisar-se-á o conteúdo das principais medidas e os motivos considerados para a sua edição. $\mathrm{O}$ exame destes últimos faz-se necessário para correlacionar o texto escrito, que lista objetivos aparentemente alinhados à ideia de proteção do trabalho, com a real efetividade da medida. 


\subsection{Medida Provisória no 927 , de 22 de março de 2020}

A Medida Provisória n ${ }^{0} .927$ não foi convertida em lei e perdeu sua validade no dia 19.07.2020. Assim, produziu efeitos de 22.03.2020 a 19.07.2020, período no qual os atos praticados entre empregador e empregado são válidos para todos os efeitos legais. Estabeleceu medidas que poderiam ser adotadas pelos empregadores para a preservação do emprego e da renda e para o enfrentamento do estado de calamidade pública e da emergência de saúde pública, de importância internacional, decorrente do novo coronavírus (COVID19).

Segundo a Exposição de Motivos EM n ${ }^{0}$ ooo81/2020 ME (BRASIL, 2020), de 22 de março de 2020, de autoria do Ministro da Economia, dirigida ao Presidente da República, a Medida Provisória viria possibilitar a implementação de medidas urgentes e imediatas de isolamento dos trabalhadores em suas residências, com a manutenção, na medida do possível, dos vínculos trabalhistas e com segurança jurídica, minimizando o impacto sobre os empregados e os empregadores. Além disso, visava a contribuir para a diminuição de despesas obrigatórias e fixas das empresas no momento de redução abrupta e drástica de faturamento em razão da retração do consumo e da emergência de saúde pública que afetava o mundo inteiro.

Um dos primeiros pontos da citada medida foi a previsão de prevalência do acordo individual escrito, celebrado entre empregado e empregador, sobre os demais instrumentos normativos, legais e negociais, respeitados os limites estabelecidos na Constituição, com clara alteração da hierarquia entre as normas jurídicas que, no campo do Direito do Trabalho, é pautada pelo princípio da norma mais favorável ao empregado.

O princípio citado manifesta-se, no mínimo, em três situações ou dimensões distintas: a) no momento de elaboração da regra, funcionando como princípio orientador da ação legislativa, portanto; 
b) no contexto de confronto entre regras concorrentes, atuando como princípio orientador do processo de hierarquização de normas trabalhistas e c) no contexto de interpretação das regras jurídicas, quando assume o papel de princípio orientador do processo de revelação do sentido da regra trabalhista (DELGADO, 2020).

A ideia é garantir ao trabalhador usufruir do diploma legal que seja mais consentâneo com a finalidade prevista no art. $7^{\circ}$, caput, da Constituição da República Federativa do Brasil - CRFB (BRASIL, 1988), que preceitua a existência de um rol mínimo de direitos, sem a exclusão de outros que visem à melhoria de sua condição social. E esta melhoria é alcançada, dentre outros fatores, pela aplicação da norma mais benéfica.

Além disso, na relação empregatícia, o acordo de vontades entre as partes está limitado à existência de um complexo de normas obrigatórias, em detrimento de normas apenas dispositivas, funcionando como instrumento assecuratório de garantias fundamentais ao trabalhador. Isso impede que o empregado possa despojar-se, por sua simples manifestação de vontade, das vantagens e das proteções que lhe são asseguradas pela ordem jurídica e pelo contrato.

Assim, a previsão de prevalência do acordo individual entre empregado e empregador sobre qualquer outro instrumento, respeitada a CRFB (BRASIL, 1988), permite identificar o propósito de alteração de regra basilar de orientação e de interpretação do Direito do Trabalho. No mesmo sentido, há o processo de conversão do acordo individual escrito em núcleo do "direito empresarial do trabalho", denominação tida como mais apropriada para refletir a inversão principiológica exacerbada (SILVA S., 2020, p. 48).

A alteração implementada tem o intuito de limitar ou excluir do alcance individual parcelas/direitos previstas em lei ou negociadas por seres coletivos, os quais, dentre as suas características, podem encetar negociações dentro de um ideal de igualdade de condições, o que não ocorre na relação entre empregado e empregador.

Outro ponto interessante tratado no diploma legal diz respeito 
às medidas que poderiam ser adotadas para o enfrentamento dos efeitos econômicos decorrentes do estado de calamidade.

A primeira delas está relacionado ao teletrabalho. A Medida Provisória facultou ao empregador, a seu critério, alterar o regime de trabalho presencial para o teletrabalho, o trabalho remoto ou outro tipo de trabalho a distância e determinar o retorno do empregado ao regime de trabalho presencial, independentemente da existência de acordos individuais ou coletivos, dispensado o registro prévio da alteração no contrato individual de trabalho. Exigiu-se, no entanto, que a alteração fosse notificada ao empregado com antecedência mínima de quarenta e oito horas, por escrito ou por meio eletrônico. Além disso, o trabalhador foi excluído das regras de controle de jornada.

A simples exclusão do trabalhador do regime de controle de jornada e, portanto, do recebimento pelas horas extraordinárias, a despeito de continuar extrapolando a jornada, especialmente quando a sua rotina e quantidade de trabalho já exigiam que assim fosse, é ignorar uma realidade que não será alterada. Ao contrário, o trabalhador continuará laborando de forma extraordinária, talvez até mais em decorrência da necessidade de adaptação ao local de trabalho, mas agora sem o recebimento dos valores devidos, transferindo-se a ele a total organização do tempo do trabalho, sem a relativização das exigências produtivas.

Quanto aos instrumentos de trabalho necessários ao desenvolvimento da atividade laboral, a legislação prevê que a responsabilidade pela aquisição, pela manutenção ou pelo fornecimento dos equipamentos tecnológicos e da infraestrutura necessária e adequada à prestação do teletrabalho, trabalho remoto ou trabalho a distância e ao reembolso de despesas arcadas pelo empregado será prevista em contrato escrito, repetindo a regra do art. 75-D da Consolidação das Leis do Trabalho - CLT (BRASIL, 1943), firmado previamente ou no prazo de trinta dias, contado da data da mudança do regime de trabalho. 
A previsão transfere ao empregado a aquisição, se for o caso, dos instrumentos de trabalho e a sua organização, para que possa desenvolver a atividade laboral. Há, assim, uma inversão de responsabilidades, pois o empregado terá gastos iniciais, que deveriam ser arcados pelo empregador.

Por outro lado, na hipótese de o empregado não possuir os equipamentos tecnológicos e a infraestrutura necessária e adequada à prestação do teletrabalho, do trabalho remoto ou do trabalho a distância, o texto legal apontava duas soluções: a) na primeira, o empregador poderia fornecer os equipamentos em regime de comodato e pagar por serviços de infraestrutura, sem que fosse considerada como verba de natureza salarial; b) na segunda hipótese, o período da jornada normal de trabalho seria computado como tempo de trabalho à disposição do empregador, o que, por certo, aumentaria o risco de o empregado ser dispensado para a contratação de outro que possuísse os equipamentos, em decorrência da natural exigência do mercado de manter a produção, sem descontinuidade.

Além disso, o legislador apontou que o tempo de uso de aplicativos e programas de comunicação fora da jornada de trabalho normal do empregado não constituiria tempo à disposição, regime de prontidão ou de sobreaviso, exceto se houvesse previsão em acordo individual ou coletivo. Dessa forma, o empregado poderia ser acionado a qualquer hora do dia, até mesmo durante o seu descanso, por meio dos diversos aplicativos de comunicação existentes atualmente, sem que isso implicasse a caracterização de aumento ou de extrapolação da jornada de trabalho, bastando, para tanto, que o empregador não assinasse acordo com o empregado em sentido contrário.

Ademais, a medida provisória permitia que o empregador informasse ao empregado sobre a antecipação de suas férias com antecedência mínima de quarenta e oito horas, por escrito ou por meio eletrônico, com a indicação do período a ser gozado, que não poderia ser inferior a cinco dias corridos. As férias poderiam ser concedidas por ato do empregador, ainda que o período aquisitivo a elas relativo não tivesse transcorrido. Facultou-se, ainda, por meio de acordo 
individual escrito, a negociação entre o empregado e o empregador sobre a antecipação de períodos futuros de férias.

Ainda dentro deste assunto, um aspecto que merece atenção foi o tratamento dado aos trabalhadores que pertencem ao grupo de risco do coronavírus, priorizados para o gozo de férias, individuais ou coletivas. Por outro lado, permitiu-se ao empregador suspender as férias ou licenças não remuneradas dos profissionais da área de saúde ou daqueles que desempenhassem funções essenciais, mediante comunicação formal da decisão ao trabalhador, por escrito ou por meio eletrônico, preferencialmente, com antecedência de quarenta e oito horas.

Sobre os valores devidos no período de gozo das férias, foi facultado ao empregador optar por efetuar o pagamento do adicional de um terço de férias após sua concessão, até a data em que é devida a gratificação natalina.

O direito do empregado de conversão de um terço de férias em abono pecuniário passou a estar sujeito à concordância do empregador, em dissonância com a previsão do art. 143 da CLT (BRASIL, 1943), que faculta o seu exercício pelo empregado, sem nenhuma condicionante.

Por fim, o prazo para o pagamento da remuneração das férias foi ampliado até o quinto dia útil do mês subsequente ao início do gozo das férias, afastando-se a aplicação do disposto no art. 145 da CLT (BRASIL, 1943), que prevê a obrigatoriedade do pagamento até dois dias antes do início do período.

Entende-se que a antecipação do gozo de férias, inclusive de períodos futuros e de períodos aquisitivos incompletos, está relacionada à ideia de assegurar o isolamento e evitar a transmissão do vírus. Contudo, destaca-se que a antecipação frustra a expectativa do empregado de gozar suas férias em período pós-pandemia, no qual teria a possibilidade de escolher como desfrutar do seu direito. Além disso, a concessão das férias decorre da necessidade de descanso físico e mental do trabalhador, após um período de trabalho. Antecipar o 
gozo das férias é permitir que, mais tarde, o trabalhador não disponha do descanso, necessário organicamente e assegurado constitucionalmente.

Foi autorizada a interrupção das atividades pelo empregador e a constituição de regime especial de compensação de jornada, por meio de banco de horas, em favor do empregador ou do empregado, estabelecido por meio de acordo coletivo ou individual formal, para a compensação no prazo de até dezoito meses, contado da data de encerramento do estado de calamidade pública. O prazo foi estendido, considerando que o art. 59, $\S 2^{\circ}$, da CLT (BRASIL, 1943) estabelece o de até um ano. Além disso, a compensação do saldo de horas poderia ser determinada pelo empregador independentemente de convenção coletiva ou acordo individual ou coletivo.

Outro aspecto trazido pela Medida Provisória foi a suspensão da obrigatoriedade de realização dos exames médicos ocupacionais, clínicos e complementares, exceto dos demissionais, sendo que até estes poderiam ser dispensados, caso o exame médico ocupacional mais recente tivesse sido realizado há menos de cento e oitenta dias. Ora, a realização de exames médicos é um direito relacionado à saúde do empregado, que não pode ser postergado, principalmente em tempos de pandemia. Por certo, se há o risco de contaminação pela frequência aos consultórios médicos, o empregador deveria adotar meios que permitissem a comunicação entre o médico e o empregado, inclusive por intermédio de plataformas digitais, a telemedicina, por exemplo. Suspender os exames pode acarretar sérios problemas com o surgimento de doenças ocupacionais.

Determinou-se, ainda, a suspensão da obrigatoriedade de realização de treinamentos periódicos e eventuais dos atuais empregados, previstos em normas regulamentadoras de segurança e de saúde no trabalho, prorrogando-os pelo prazo de noventa dias, contado da data de encerramento do estado de calamidade pública, o que colocava em risco o empregado, que deveria realizar as suas atividades sem treinamento adequado, o que é grave, especialmente quando realiza atividades perigosas. 
No entanto, facultou-se a realização de treinamentos na modalidade de ensino a distância. Especificamente sobre as Comissões Internas de Prevenção de Acidentes - CIPA, previu-se que os mandatos dos seus integrantes poderiam ser mantidos até o encerramento do estado de calamidade pública e os processos eleitorais em curso poderiam ser suspensos.

Um dispositivo bastante inusitado era o artigo 18 da MP $\mathrm{n}^{\circ}$ 927/2020, relativo à possibilidade de direcionamento do trabalhador para qualificação, com a suspensão do contrato de trabalho, por meio de acordo individual, pelo prazo de até quatro meses. Dessa forma, o empregado ficaria sem receber salário por quatro meses, salvo uma ajuda, quando o empregador assim entendesse cabível, que sequer teria natureza salarial, para fins de qualificação em cursos ofertados pelo empregador. Este capítulo foi integralmente revogado no dia seguinte à sua edição pela MP 928, de 23 de março de 2020 (BRASIL, 2020).

Outra medida foi o diferimento do recolhimento do Fundo de Garantia do Tempo de Serviço, com a suspensão de sua exigibilidade pelos empregadores, referente às competências de março, abril e maio de 2020, com vencimento em abril, maio e junho de 2020, respectivamente. Além disso, facultou-se o recolhimento das competências de março, abril e maio de 2020 de forma parcelada, sem a incidência da atualização, da multa e dos encargos. A medida objetivou diminuir o impacto da pandemia nas finanças do empregador.

Além disso, permitiu-se aos estabelecimentos de saúde, mediante acordo individual escrito, mesmo em atividades insalubres e em jornada de doze horas de trabalho por trinta e seis de descanso, prorrogar a jornada e adotar escalas de horas suplementares entre a décima terceira e a vigésima quarta hora do intervalo interjornada, sem que houvesse penalidade administrativa, garantido o repouso semanal remunerado.

A medida provisória em estudo foi objeto de diversas ações 
diretas de inconstitucionalidade perante o Supremo Tribunal Federal. A título de exemplo, citamos as ADIs no ${ }^{\circ} .6342, n^{\circ} .6344, n^{\circ} .6346, n^{\circ}$. 6352, $\mathrm{n}^{0} .6354, \mathrm{n}^{\circ} .6375$ e a $\mathrm{n}^{\circ} .6380$ (BRASIL, 2020). Nesta última, o Supremo Tribunal Federal, na Sessão Virtual realizada no período de 8.5.2020 a 14.5.2020, concedeu, parcialmente, a medida liminar para suspender a eficácia do art. 29 da Medida Provisória ${ }^{\circ}$. 927, o qual previa que os casos de contaminação pelo coronavírus (COVID-19) não seriam considerados ocupacionais, exceto mediante comprovação do nexo causal, o que, sem dúvidas, acarretaria prejuízos e dificuldades probatórias ao empregado.

Do mesmo modo, na ADI no 6342 (BRASIL, 2020), o Supremo Tribunal Federal, por maioria, negou referendo ao indeferimento da medida cautelar em relação ao artigo 31 da Medida Provisória 927/2020 e, nos termos do voto do Ministro Alexandre de Moraes, suspendeu a sua eficácia. Segundo o citado dispositivo, durante o período de cento e oitenta dias, contado da data de entrada em vigor desta Medida Provisória, os Auditores Fiscais do Trabalho do Ministério da Economia atuariam de maneira orientadora, exceto quanto às seguintes irregularidades: falta de registro de empregado, a partir de denúncias; situações de grave e iminente risco, somente para as irregularidades imediatamente relacionadas à configuração da situação; ocorrência de acidente de trabalho fatal apurado por meio de procedimento fiscal de análise de acidente, somente para as irregularidades imediatamente relacionadas às causas do acidente; $\mathrm{e}$ trabalho em condições análogas às de escravo ou trabalho infantil.

Por fim, a MP 927/2020 adotou uma cláusula de convalidação de atos praticadas pelos empregadores no período dos trinta dias anteriores à data de sua entrada em vigor da medida, desde que não contrariassem os seus dispositivos. A cláusula de validação ampla dos atos praticados pelo empresariado denota o real intento da edição do citado marco regulatório, qual seja, assegurar proteção jurídica ao empresário, independentemente do grau de violação ou precarização suportado pelo trabalhador. 


\subsection{Medida Provisória no 936, convertida na lei no 14.020, de 6 de julho de 2020}

A Medida Provisória ${ }^{0}$ 936, de $1^{\circ}$ de abril de 2020 (BRASIL, 2020), segundo a Exposição de Motivos no ${ }^{0}$ 00104/2020 ME (BRASIL, 2020), tinha o objetivo de preservar o emprego e a renda, garantir a continuidade das atividades empresariais, bem como de reduzir o impacto social diante da paralisação de atividades e da restrição de mobilidade. Seu conteúdo revelava a existência de medidas de flexibilização do contrato de trabalho e das relações trabalhistas. Além disso, destacava a contribuição para a diminuição de despesas obrigatórias e fixas das empresas durante o período de redução drástica de faturamento em razão da abrupta retração do consumo e da emergência em saúde pública.

A citada medida instituiu o Programa Emergencial de Manutenção do Emprego e da Renda, com o objetivo de preservar o emprego e a renda, de garantir a continuidade das atividades laborais e empresariais e de reduzir o impacto social decorrente das consequências do estado de calamidade pública e da emergência de saúde pública. Para tanto, foram traçadas três medidas principais, quais sejam, o pagamento do Benefício Emergencial de Preservação do Emprego e da Renda, a redução proporcional da jornada de trabalho e do salário e a suspensão temporária do contrato de trabalho.

O pagamento do Benefício Emergencial de Preservação do Emprego e da Renda fora previsto para as hipóteses de redução proporcional de jornada de trabalho e de salário e de suspensão temporária do contrato de trabalho, custeado com recursos da União, de prestação mensal e devido a partir da data do início das medidas, devendo ser pago enquanto perdurar essa situação.

Ponto interessante está relacionado ao montante a ser pago. 
Sua base de cálculo será o valor mensal do seguro-desemprego a que o empregado teria direito, observadas as seguintes disposições: I - na hipótese de redução de jornada de trabalho e de salário, será calculado aplicando-se sobre a base de cálculo o percentual da redução; e II - na hipótese de suspensão temporária do contrato de trabalho, terá valor mensal: a) equivalente a 100\% (cem por cento) do valor do segurodesemprego a que o empregado teria direito, na hipótese prevista no caput do art. $8^{\circ}$ desta Lei; ou b) equivalente a $70 \%$ (setenta por cento) do valor do seguro-desemprego a que o empregado teria direito, na hipótese prevista no $\S 5^{\circ}$ do art. $8^{\circ}$ desta Lei.

Nota-se que o estabelecimento do valor mensal do segurodesemprego como base de cálculo para o benefício citado implica, a depender do valor recebido pelo empregado, redução de sua capacidade de consumo, em claro prejuízo ao empregado, à sua família e ao próprio mercado, que necessita do consumidor para a aquisição de produtos.

Outra medida foi a redução proporcional da jornada de trabalho e do salário. A lei prevê que o empregador poderá acordar a redução proporcional de jornada de trabalho e de salário de seus empregados, de forma setorial, departamental, parcial ou na totalidade dos postos de trabalho, por até 90 (noventa) dias, prorrogáveis por prazo determinado, por ato do Poder Executivo, observados os seguintes requisitos: preservação do valor do salário-hora de trabalho; pactuação por convenção coletiva de trabalho, acordo coletivo de trabalho ou acordo individual escrito entre empregador e empregado e, na hipótese de pactuação por acordo individual escrito, encaminhamento da proposta de acordo ao empregado com antecedência de, no mínimo, 2 (dois) dias corridos, e redução da jornada de trabalho e do salário exclusivamente nos seguintes percentuais: a) 25\% (vinte e cinco por cento); b) 50\% (cinquenta por cento) e c) $70 \%$ (setenta por cento).

Além das medidas anteriores, há também a possibilidade de suspensão temporária do contrato de trabalho. Nessa situação, o empregador poderá acordar a suspensão temporária do contrato de 
trabalho de seus empregados, de forma setorial, departamental, parcial ou na totalidade dos postos, pelo prazo máximo de 60 (sessenta) dias, fracionável em 2 (dois) períodos de até 30 (trinta) dias, podendo ser prorrogado por prazo determinado por ato do Poder Executivo.

Interessa observar que, ao contrário da MP 927/2020, que fundamentava várias decisões exclusivamente em acordos individuais, a suspensão temporária do contrato de trabalho deverá ser pactuada por convenção coletiva de trabalho, acordo coletivo de trabalho ou acordo individual escrito entre empregador e empregado, nesta última hipótese devendo a proposta ser encaminhada ao empregado com antecedência de, no mínimo, 2 dias corridos.

Ainda segundo o texto legal, durante o período de suspensão temporária do contrato de trabalho, o empregado terá direito a todos os benefícios concedidos pelo empregador aos seus empregados e ficará autorizado a contribuir para o Regime Geral de Previdência Social na qualidade de segurado facultativo.

A respeito do restabelecimento do contrato de trabalho, a lei estabelece o prazo de 2 (dois) dias corridos, contado da cessação do estado de calamidade pública, da data estabelecida como termo de encerramento do período de suspensão pactuado ou da data de comunicação do empregador, para que o empregador informe ao empregado sua decisão de antecipar o fim do período de suspensão pactuado.

Por outro lado, com o intuito de evitar fraudes nas relações laborais, o legislador pontua que se, durante o período de suspensão temporária do contrato de trabalho, o empregado mantiver as suas atividades de trabalho, ainda que parcialmente, por meio de teletrabalho, trabalho remoto ou trabalho a distância, ficará descaracterizada a suspensão temporária do contrato de trabalho, e o empregador estará sujeito ao pagamento imediato da remuneração e dos encargos sociais e trabalhistas referentes a todo o período, às penalidades previstas na legislação em vigor e às sanções previstas em 
convenção coletiva ou acordo coletivo de trabalho.

É relevante informar que o legislador, no tocante ao pagamento de ajuda compensatória aos trabalhadores, fez uma diferenciação com base na receita bruta da empresa. Assim, se a empresa tiver auferido, no ano-calendário de 2019, receita bruta superior a $\mathrm{R} \$ 4.800 .000,00$ (quatro milhões e oitocentos mil reais) somente poderá suspender o contrato de trabalho de seus empregados mediante o pagamento de ajuda compensatória mensal no percentual de 30\% (trinta por cento) sobre o salário do empregado, durante o período de suspensão temporária do contrato de trabalho pactuado. A empresa que não atingir aquele patamar de renda bruta, está dispensada de efetuar o pagamento da citada ajuda.

Há ainda a possibilidade do Benefício Emergencial de Preservação do Emprego e da Renda ser acumulado com o pagamento, pelo empregador, de ajuda compensatória mensal, em decorrência da redução proporcional de jornada de trabalho e de salário ou da suspensão temporária de contrato de trabalho. Neste caso, a ajuda compensatória mensal deverá ter seu valor definido em negociação coletiva ou no acordo individual escrito pactuado e terá natureza indenizatória, não integrando a base de cálculo do imposto sobre a renda, contribuição previdenciária e dos depósitos no Fundo de Garantia do Tempo de Serviço (FGTS).

Considerando o objetivo de manutenção do emprego, a despeito da redução salarial do empregado, o legislador assegurou garantia provisória no emprego ao empregado que receber o Benefício Emergencial de Preservação do Emprego e da Renda em decorrência da redução da jornada de trabalho e do salário ou da suspensão temporária do contrato de trabalho de que trata essa Lei.

A garantia estará assegurada durante o período acordado de redução da jornada de trabalho e do salário ou de suspensão temporária do contrato de trabalho; após o restabelecimento da jornada de trabalho e do salário ou o encerramento da suspensão temporária do contrato de trabalho, por período equivalente ao acordado para a redução ou a suspensão; e, no caso da empregada 
gestante, por período equivalente ao acordado para a redução da jornada de trabalho e do salário ou para a suspensão temporária do contrato de trabalho, contado a partir do término do período da garantia estabelecida na alínea "b" do inciso II do caput do art. 10 do Ato das Disposições Constitucionais Transitórias (BRASIL, 1988).

Além disso, se houver dispensa sem justa causa durante o período de garantia provisória no emprego, o empregador estará sujeito ao pagamento, além das parcelas rescisórias previstas na legislação em vigor, de indenização no percentual de 50\% (cinquenta por cento) do salário a que o empregado teria direito no período de garantia provisória no emprego, na hipótese de redução de jornada de trabalho e de salário igual ou superior a $25 \%$ (vinte e cinco por cento) e inferior a 50\% (cinquenta por cento); 75\% (setenta e cinco por cento) do salário a que o empregado teria direito no período de garantia provisória no emprego, na hipótese de redução de jornada de trabalho e de salário igual ou superior a 50\% (cinquenta por cento) e inferior a $70 \%$ (setenta por cento); ou 100\% (cem por cento) do salário a que o empregado teria direito no período de garantia provisória no emprego, nas hipóteses de redução de jornada de trabalho e de salário em percentual igual ou superior a 70\% (setenta por cento) ou de suspensão temporária do contrato de trabalho.

Com destaque parcial para a autonomia coletiva, fixou-se que a convenção coletiva ou o acordo coletivo de trabalho poderão estabelecer redução de jornada de trabalho e de salário em percentuais diversos dos previstos acima, mas o valor do Benefício Emergencial de Preservação do Emprego e da Renda está fixado legalmente, com variação dependente do percentual de redução de jornada e do salário.

Além das várias diferenciações, o texto legal ainda faz uma diferença quanto à aplicabilidade da lei, considerando, dentre outros aspectos, o valor salarial do empregado e a receita bruta do empregador. Nesse cenário, as medidas acima expostas serão implementadas por meio de acordo individual escrito ou de negociação coletiva aos empregados: i) com salário igual ou inferior a 
$\mathrm{R} \$ 2.090,00$ (dois mil e noventa reais), na hipótese de o empregador ter auferido, no ano-calendário de 2019, receita bruta superior a $\mathrm{R}$ \$ 4.800.000,00 (quatro milhões e oitocentos mil reais); ii) com salário igual ou inferior a $\mathrm{R} \$ 3.135, \mathrm{oo}$ (três mil, cento e trinta e cinco reais), na hipótese de o empregador ter auferido, no ano-calendário de 2019, receita bruta igual ou inferior a $\mathrm{R} \$ 4.800 .000,00$ (quatro milhões e oitocentos mil reais); iii) portadores de diploma de nível superior e que percebam salário mensal igual ou superior a 2 (duas) vezes o limite máximo dos benefícios do Regime Geral de Previdência Social.

Para os empregados não enquadrados nas faixas acima, as medidas somente poderão ser estabelecidas por convenção coletiva ou acordo coletivo de trabalho, salvo nas seguintes hipóteses, nas quais se admite a pactuação por acordo individual escrito: redução proporcional de jornada de trabalho e de salário de $25 \%$ (vinte e cinco por cento), redução proporcional de jornada de trabalho e de salário ou suspensão temporária do contrato de trabalho quando do acordo não resultar diminuição do valor total recebido mensalmente pelo empregado, incluídos neste valor o Benefício Emergencial de Preservação do Emprego e da Renda, a ajuda compensatória mensal e, em caso de redução da jornada, o salário pago pelo empregador em razão das horas de trabalho.

Quanto à formalidade da pactuação, o legislador prevê que poderá ser realizada por quaisquer meios físicos ou eletrônicos eficazes, sendo que os acordos individuais de redução de jornada de trabalho e de salário ou de suspensão temporária do contrato de trabalho deverão ser comunicados pelos empregadores ao respectivo sindicato da categoria profissional, no prazo de até 10 (dez) dias corridos, contado da data de sua celebração.

E se, após a pactuação de acordo individual, houver a celebração de convenção coletiva ou acordo coletivo de trabalho com cláusulas conflitantes com as do acordo individual, deverão ser observadas as seguintes regras: a aplicação das condições estabelecidas no acordo individual em relação ao período anterior ao da negociação coletiva e 
a partir da entrada em vigor da convenção coletiva ou do acordo coletivo de trabalho, a prevalência das condições estipuladas na negociação coletiva, naquilo em que conflitarem com as condições estipuladas no acordo individual.

Por outro lado, o legislador resgata o princípio da norma mais favorável ao dispor que as condições do acordo individual prevalecerão sobre a negociação coletiva quando forem mais favoráveis ao trabalhador, regra cuja possibilidade de aplicação é bastante mitigada em face da prevalência da ideia do lucro, correspondente à redução do custo com a mão de obra.

\subsection{Medida Provisória no. 945, de 4 de abril de 2020}

O texto normativo dispõe sobre medidas especiais em resposta à pandemia decorrente da COVID-19 com o objetivo de garantir a preservação das atividades portuárias, consideradas essenciais e a cessão de uso especial de pátios sob administração militar.

Segundo a Exposição de Motivos $n^{0}$ 00011/2020 MINFRA, de 21 de Março de 2020 (BRASIL, 2020), há um risco maior de contaminação para grupos de trabalhadores que laboram em regime de confinamento, situação bastante comum no setor portuário, em que alguns dos trabalhadores compartilham instalações físicas.

Há um especial destaque para a importância do setor portuário para a economia do país. Segundo consta na EM $n^{0}$ 00011/2020 MINFRA, "o setor portuário [...] representa cerca de $95 \%$ da corrente de comércio exterior que passa pelo país e movimenta, em média, 293 bilhões anualmente, o que representa $14,2 \%$ do PIB brasileiro" (BRASIL, 2020).

Consta, no texto legal, que o Órgão Gestor de Mão de Obra não poderá escalar trabalhador portuário avulso que apresente sintomas 
compatíveis com a COVID-19 ou que faça parte do grupo de risco. Durante o período de impedimento de escalação, o trabalhador portuário avulso terá direito ao recebimento de indenização compensatória mensal no valor correspondente a cinquenta por cento sobre a média mensal recebida por ele por intermédio do Órgão Gestor de Mão de Obra, entre $1^{\circ}$ de outubro de 2019 e 31 de março de 2020.

A redução significativa da remuneração do trabalhador, em um cenário de grande crise econômica e sanitária, permite identificar que a preocupação com o capital prepondera sobre a ideia de manutenção da qualidade de vida e do bem estar do trabalhador.

A despeito da existência de uma cláusula de reajuste do valor, a qual prevê que, na hipótese de o aumento de custos com o trabalho portuário avulso decorrente da indenização ter impacto sobre os contratos de arrendamentos já firmados, estes deverão ser alterados de maneira a promover o reequilíbrio econômico-financeiro, não há nada que permita um reequilíbrio em prol do trabalhador.

Além disso, o benefício a ser pago aos trabalhadores portuários avulsos terá natureza indenizatória. Identifica-se, portanto, que a manutenção do vínculo precariza a vida do trabalhador, em benefício do setor econômico, considerado essencial para o crescimento do país.

\subsection{Portaria no 16.655, de 14 de julho de 2020, do Ministério da Economia}

A portaria disciplina a recontratação nos casos de rescisão sem justa causa, durante o estado de calamidade pública de que trata o Decreto Legislativo $\mathrm{n}^{0} 6$, de 20 de março de 2020 (BRASIL, 2020). Em seus considerandos, consta a necessidade de afastar a presunção de fraude nos casos de recontratação de empregado em período inferior a noventa dias subsequentes à data da rescisão contratual, durante a ocorrência do estado de calamidade pública.

Nesse sentido, dispõe que não se presumirá fraudulenta a 
rescisão de contrato de trabalho sem justa causa seguida de recontratação, dentro dos noventa dias subsequentes à data em que, formalmente, a rescisão operou-se, desde que mantidos os mesmos termos do contrato rescindido. Por outro lado, a recontratação poderá se dar em termos diversos do contrato rescindido quando houver previsão neste sentido em instrumento decorrente de negociação coletiva.

A portaria permite que o empregador dispense e, em seguida, contrate novamente o empregado. Por um lado, o empregador não terá custos com a manutenção do emprego. Por outro, o empregado, agora desempregado, ficará sem a sua principal fonte de renda.

Se o objetivo dos marcos legislativos é a manutenção do emprego, sem dúvida, a portaria apresenta-se em dissonância com ele, pois, ao estabelecer, expressamente, a não existência de fraude, permite a dispensa imediata de empregados naquelas empresas com atividade suspensa ou paralisada, com a readmissão na ocasião do retorno. Entretanto, não cuida da preservação do emprego, e sim da higidez econômica do empregador.

Até este momento, analisaram-se as medidas específicas voltadas ao empregado, reputando como tal aquele que possui contrato de emprego, devidamente formalizado, sujeito às regulações previstas na CLT (BRASIL, 1943). Entretanto, considerando que a classe trabalhadora não se subsume exclusivamente na relação de emprego, entende-se relevante expor a medida adotada para os trabalhadores informais, o que passamos a realizar.

\subsection{Lei no. 13.982, de 2 de abril de 2020 - Auxílio Emergencial}

Para os trabalhadores informais, a medida adotada pelo governo, de maior impacto, foi a concessão do Auxílio Emergencial.

Segundo o texto legal, durante o período de 3 (três) meses, a 
contar da publicação da lei, seria concedido auxílio emergencial no valor de $\mathrm{R} \$ 600,00$ (seiscentos reais) mensais ao trabalhador que cumprisse, cumulativamente, os seguintes requisitos: a) ser maior de 18 (dezoito) anos de idade, salvo no caso de mães adolescentes; b) não ter emprego formal ativo; c) não ser titular de benefício previdenciário ou assistencial ou beneficiário do seguro-desemprego ou de programa de transferência de renda federal, com ressalva do Bolsa Família; d) ter renda familiar mensal per capita de até $1 / 2$ (meio) salário-mínimo ou a renda familiar mensal total de até 3 (três) salários mínimos; e) não ter recebido, no ano de 2018, rendimentos tributáveis acima de $\mathrm{R} \$ 28.559,70$ (vinte e oito mil, quinhentos e cinquenta e nove reais e setenta centavos) e que exerça atividade na condição de: i) microempreendedor individual (MEI); ii) contribuinte individual do Regime Geral de Previdência Social; ou iii) trabalhador informal, seja empregado, autônomo ou desempregado, de qualquer natureza, inclusive o intermitente inativo, inscrito no Cadastro Único para Programas Sociais do Governo Federal (CadÚnico) até 20 de março de 2020.

O auxílio poderá ser pago para até dois membros da mesma família. No caso de mulher provedora da família monoparental, foi previsto o recebimento de duas cotas.

Por não ser cumulativo, o pagamento do auxílio emergencial substitui, automática e temporariamente, o pagamento do benefício associado ao programa Bolsa Família sempre que for mais vantajoso para o beneficiário.

Segundo Carvalho (2020, p. 1), cerca de 4,5 milhões de domicílios brasileiros, o que representa $6,5 \%$ do total de lares no país, sobreviveram, em julho, apenas com a renda do Auxílio Emergencial. Entre os domicílios mais pobres, os rendimentos atingiram 124\% do que seriam com as rendas habituais.

O benefício começou a ser pago no mês de abril. Em junho, por meio do Decreto $\mathrm{n}^{\mathrm{0}}$ 10.412, de 30 de junho de 2020 (BRASIL, 2020), foi prorrogado pelo período de dois meses, com a manutenção do valor de $\mathrm{R} \$ 600,00$. 
O Mundo Do Trabalho Em Tempos De Pandemia No Brasil: 0 Incremento Da...

No dia 2 de setembro de 2020, foi editada a Medida Provisória $\mathrm{n}^{\mathrm{O}}$. 1.000 (BRASIL, 2020), com a instituição do auxílio emergencial residual para o enfrentamento da emergência de saúde pública. Tratase, de fato, da prorrogação do auxílio emergencial instituído pela Lei $\mathrm{n}^{\mathrm{o}}$. 13.982 (BRASIL, 2020), até 31 de dezembro de 2020, com a redução do valor da parcela para a quantia de $\mathrm{R} \$ 300,00$.

Diante de tal panorama, identifica-se que os trabalhadores informais, especialmente os que não puderem realizar suas atividades habituais em decorrência do isolamento social, por serem integrantes de grupo de risco, terão um decréscimo de renda superior à metade do salário mínimo vigente.

Os marcos legislativos expostos nesta seção não esgotam as medidas que afetaram os contratos de trabalho nesse período de pandemia. Procurou-se apresentar os mais relevantes, abrangentes e complexos normativos, com as suas peculiaridades, a fim de compreender como a questão de proteção ao emprego e à renda foi subordinada aos interesses do capital.

Em seguida, são analisados os dados de emprego e de renda durante o período da pandemia para, ao final, responder-se a questãoproblema deste estudo.

\section{A RESPOSTA dO BRASIL À COVID-19: O AUMENTO DO DESEMPREGO E DA PRECARIZAÇÃO DO TRABALHO}

Iniciaremos a presente seção abordando os níveis de desemprego e a taxa de desocupação das pessoas de 14 anos ou mais descritos na Pesquisa Nacional por Amostra de Domicílios Contínua (PNAD Contínua-Junho/2020), elaborada pelo IBGE (2020):

PNAD Contínua - Divulgação: Junho de 2020 


\begin{tabular}{|c|c|c|c|c|c|c|c|c|c|}
\hline \multicolumn{8}{|c|}{ Trimestre Móvel: mar-abr-maio/2020 } & \multirow{2}{*}{\multicolumn{2}{|c|}{$\begin{array}{c}\text { E - Estável } \\
\text { Variação em } \\
\text { relação ao } \\
\text { trimestre mar- } \\
\text { abr-maio/2019 }\end{array}$}} \\
\hline \multirow{2}{*}{\multicolumn{2}{|c|}{ Indicadores }} & \multicolumn{3}{|c|}{$\begin{array}{l}\text { Estimativas dos trimestres } \\
\text { móveis }\end{array}$} & \multicolumn{3}{|c|}{$\begin{array}{c}\text { Variação em relação ao } \\
\text { trimestre dez-jan-fev/2020 }\end{array}$} & & \\
\hline & & $\begin{array}{l}\text { mar-abr- } \\
\text { maio } \\
2019\end{array}$ & $\begin{array}{l}\text { dez-jan- } \\
\text { fev } \\
2020\end{array}$ & $\begin{array}{l}\text { mar- } \\
\text { abri- } \\
\text { maio } \\
2020\end{array}$ & Situação & $\begin{array}{l}\text { Difere } \\
\text { nça }\end{array}$ & VAR\% & Situação & $\begin{array}{l}\text { Difere } \\
\text { nça }\end{array}$ \\
\hline \multirow{3}{*}{ Taxas (\%) } & $\begin{array}{l}\text { TAXA DE } \\
\text { DESOCUPAÇÃO }\end{array}$ & 12,3 & 11,6 & 12,9 & $\mathbf{C}$ & $\mathbf{1 , 2}$ & - & $\mathbf{C}$ & $\mathbf{0 , 6}$ \\
\hline & Nível da ocupação & 54,5 & 54,5 & 49,5 & $\mathrm{D}$ & -5 & - & $\mathrm{D}$ & -5 \\
\hline & $\begin{array}{l}\text { Taxa de participação na } \\
\text { força de trabalho }\end{array}$ & 62,1 & 61,7 & 56,8 & $\mathrm{D}$ & $-4,8$ & - & $\mathrm{D}$ & $-5,3$ \\
\hline \multirow{18}{*}{$\begin{array}{c}\text { Ocupadas } \\
\text { por } \\
\text { posição } \\
\text { na } \\
\text { ocupação } \\
\text {, setor e } \\
\text { categoria } \\
\text { do } \\
\text { emprego } \\
\text { no } \\
\text { trabalho } \\
\text { principal }\end{array}$} & Empregado & 62.333 & 62.848 & 57.608 & $\mathrm{D}$ & $\begin{array}{c}- \\
5.240 \\
\end{array}$ & $-8,3$ & $\mathrm{D}$ & -4.725 \\
\hline & Setor privado & 44.606 & 45.269 & 40.321 & $\mathrm{D}$ & $\begin{array}{c}- \\
4.948 \\
\end{array}$ & $-10,9$ & $\mathrm{D}$ & $\begin{array}{c}- \\
4.285 \\
\end{array}$ \\
\hline & Com carteira & 33.222 & 33.624 & 31.103 & $\mathrm{D}$ & $\begin{array}{c}- \\
2.522 \\
\end{array}$ & $-7,5$ & $\mathrm{D}$ & -2.119 \\
\hline & Sem carteira & 11.384 & 11.644 & 9.218 & $\mathrm{D}$ & $\begin{array}{c}- \\
2.426\end{array}$ & $-20,8$ & $\mathrm{D}$ & -2.166 \\
\hline & Trabalhador doméstico & 6.183 & 6.209 & 5.033 & $\mathrm{D}$ & -1.176 & $-18,9$ & $\mathrm{D}$ & -1.151 \\
\hline & Com carteira & 1.769 & 1.717 & 1.463 & $\mathrm{D}$ & -254 & $-14,8$ & $\mathrm{D}$ & -306 \\
\hline & Sem carteira & 4.414 & 4.492 & 3.569 & $\mathrm{D}$ & -922 & $-20,5$ & $\mathrm{D}$ & -845 \\
\hline & Setor público & 11.543 & 11.370 & 12.255 & $\mathrm{C}$ & 884 & 7,8 & $\mathrm{C}$ & 711 \\
\hline & Com carteira & 1.272 & 1.203 & 1.206 & $\mathrm{E}$ & 3 & 0,3 & $\mathrm{E}$ & -66 \\
\hline & $\begin{array}{l}\text { Militar e funcionário } \\
\text { público estatutário }\end{array}$ & 7.888 & 7.896 & 8.560 & $\mathrm{C}$ & 664 & 8,4 & $\mathrm{C}$ & 672 \\
\hline & Sem carteira & 2.383 & 2.271 & 2.488 & $\mathrm{C}$ & 217 & 9,5 & $\mathrm{E}$ & 105 \\
\hline & Empregador & 4.422 & 4.411 & 4.034 & $\mathrm{D}$ & -377 & $-8,5$ & $\mathrm{D}$ & -388 \\
\hline & Com CNPJ & 3.533 & 3.601 & 3.325 & $\mathrm{D}$ & -276 & $-7,7$ & $\mathrm{D}$ & -208 \\
\hline & Sem CNPJ & 889 & 810 & 709 & $\mathrm{D}$ & -101 & $-12,5$ & $\mathrm{D}$ & -180 \\
\hline & Conta própria & 24.033 & $24 \cdot 477$ & 22.415 & $\mathrm{D}$ & $\begin{array}{c}- \\
2.062 \\
\end{array}$ & $-8,4$ & $\mathrm{D}$ & -1.618 \\
\hline & Com CNPJ & 4.754 & $5 \cdot 315$ & 5.493 & $\mathrm{E}$ & 177 & 3,3 & $\mathrm{C}$ & 739 \\
\hline & Sem CNPJ & 19.279 & 19.161 & 16.922 & $\mathrm{D}$ & $\begin{array}{c}- \\
2.240 \\
\end{array}$ & $-11,7$ & $\mathrm{D}$ & -2.357 \\
\hline & $\begin{array}{l}\text { Trabalhador familiar } \\
\text { auxiliar }\end{array}$ & 2.160 & 1.974 & 1.879 & $\mathrm{E}$ & -95 & $-4,8$ & $\mathrm{D}$ & -281 \\
\hline \multirow{10}{*}{$\begin{array}{l}\text { Ocupadas } \\
\text { por } \\
\text { grupament } \\
\text { os de } \\
\text { atividades } \\
\text { do trabalho } \\
\text { principal }\end{array}$} & $\begin{array}{l}\text { Agricultura, pecuária, } \\
\text { produção florestal, pesca } \\
\text { e aquicultura }\end{array}$ & 8.573 & 8.370 & 7.993 & $\mathrm{D}$ & -377 & $-4,5$ & $\mathrm{D}$ & -580 \\
\hline & Indústria geral & 11.859 & 12.165 & 10.934 & $\mathrm{D}$ & -1.230 & $-10,1$ & $\mathrm{D}$ & -925 \\
\hline & Construção & 6.565 & 6.624 & 5.541 & $\mathrm{D}$ & -1.083 & $-16,4$ & $\mathrm{D}$ & -1.024 \\
\hline & $\begin{array}{l}\text { Comércio, reparação de } \\
\text { veículos automotores e } \\
\text { motocicletas }\end{array}$ & $17 \cdot 519$ & 17.853 & 15.870 & $\mathrm{D}$ & -1.983 & $-11,1$ & $\mathrm{D}$ & -1.649 \\
\hline & $\begin{array}{l}\text { Transporte, } \\
\text { armazenagem e correio }\end{array}$ & 4.881 & $4 \cdot 970$ & $4 \cdot 550$ & $\mathrm{D}$ & -420 & $-8,4$ & $\mathrm{D}$ & -331 \\
\hline & Alojamento e alimentação & 5.429 & 5.613 & 4.373 & $\mathrm{D}$ & -1.240 & $-22,1$ & $\mathrm{D}$ & -1.056 \\
\hline & $\begin{array}{l}\text { Informação, comunicação } \\
\text { e atividades financeiras, } \\
\text { imobiliárias, profissionais } \\
\text { e administrativas }\end{array}$ & 10.527 & 10.582 & 10.240 & $\mathrm{D}$ & -343 & $-3,2$ & $\mathrm{E}$ & -288 \\
\hline & $\begin{array}{l}\text { Administração } \\
\text { pública, defesa, } \\
\text { seguridade social, } \\
\text { educação, saúde } \\
\text { humana e serviços } \\
\text { sociais }\end{array}$ & 16.341 & 16.186 & 16.934 & $\mathrm{C}$ & 748 & 4,6 & $\mathrm{C}$ & 593 \\
\hline & Outros serviços & 4.976 & 5.082 & 4.407 & $\mathrm{D}$ & -675 & $-13,3$ & $\mathrm{D}$ & -570 \\
\hline & Serviços domésticos & 6.233 & 6.243 & 5.074 & $\mathrm{D}$ & -1.170 & $-18,7$ & $\mathrm{D}$ & -1.159 \\
\hline
\end{tabular}

Fonte: Pesquisa Nacional por Amostra de Domicílios Contínua (PNAD ContínuaJunho/2020) - IBGE

Os dados acima apontam que, no último trimestre março/abril/maio de 2020, o Brasil apresentou uma taxa de desocupação, ou seja, a porcentagem de pessoas com força de trabalho que estão desempregadas, para a população de 14 anos ou mais, no percentual de $12,9 \%$, o que representa uma perda, aproximada, de 7,9 
milhões de postos de trabalho, ou seja, uma variação de $1,2 \%$ em relação aos três trimestres móveis anteriores e, ainda, o,6\% de variação em relação ao mesmo trimestre móvel do ano anterior. É a maior taxa de desemprego desde o primeiro trimestre de 2018, que contabilizou $13,1 \%$.

O crescimento da taxa de desocupação é reflexo da redução dos postos de trabalho e repercute no formação e declínio da renda das famílias brasileiras, revelando que mais pessoas estão desempregadas e um número maior de famílias está recebendo um valor abaixo do seu rendimento habitual.

De acordo com a discriminação feita na tabela acima, quanto à posição, setor e categoria do emprego, identifica-se que os setores (grupamentos de atividade do trabalho principal) apresentaram taxa de ocupação em ordem decrescente no último trimestre, com exceção para os da Administração Pública, defesa, seguridade social, educação, saúde humana e serviços sociais.

$\mathrm{O}$ fato de grande parte dos setores empresariais, atividades e categorias terem apresentado decréscimo relacionado à taxa de ocupação permite dizer que são parte de uma conjuntura que não distingue atividade, ou seja, trata-se de uma redução de postos de trabalho de forma generalizada, provocando a redução severa dos postos formais. Neste ponto, destaca-se que o número de empregados com carteira assinada caiu para o menor nível da série histórica e, pela primeira vez, menos da metade da população em idade de trabalhar está ocupada, contabilizando apenas 49,5\%.

Feito o exame sobre a redução dos postos de trabalho, passa-se à análise do rendimento das famílias brasileiras. Com relação ao rendimento médio mensal das pessoas de 14 anos ou mais, no trimestre em análise, foram obtidos os seguintes percentuais e dados: 


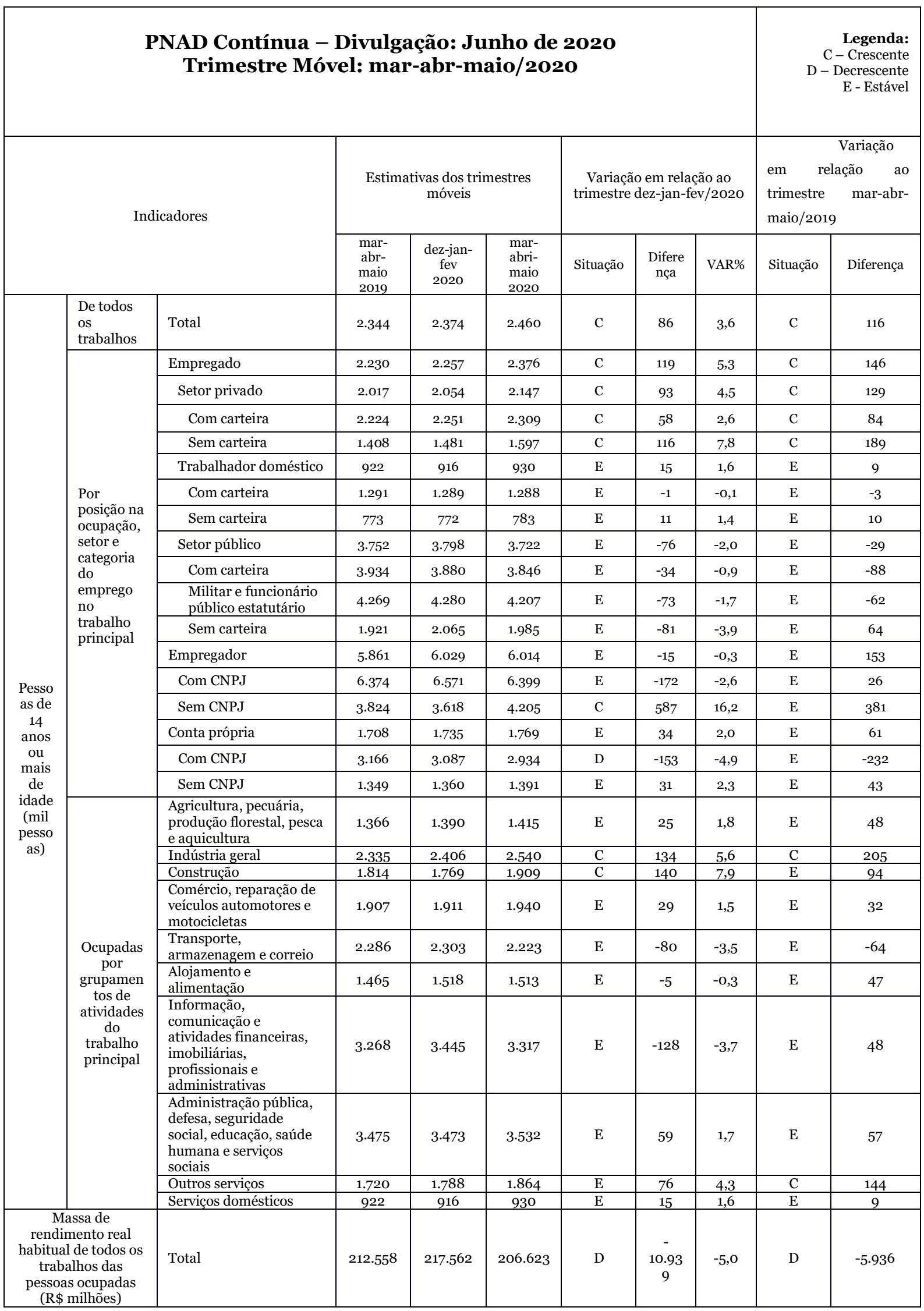

Fonte: Pesquisa Nacional por Amostra de Domicílios Contínua (PNAD ContínuaJunho/2020) - IBGE 
O Mundo Do Trabalho Em Tempos De Pandemia No Brasil: 0 Incremento Da...

A pesquisa revela que o rendimento médio real de todos os trabalhadores, habitualmente recebido por mês, pelas pessoas de 14 anos ou mais de idade, ocupadas na semana de referência, com rendimento de trabalho, totalizou $\mathrm{R} \$ 2.460,00$ (dois mil, quatrocentos e sessenta reais), com uma variação percentual em relação a três trimestres móveis anteriores de 3,6\% e com uma variação percentual em relação ao mesmo trimestre móvel do ano anterior no quantitativo de 4,9\%. Por grupamentos de atividade do trabalho principal, o maior rendimento médio é encontrado na administração pública, defesa, seguridade social, educação, saúde humana e serviços sociais e, o menor rendimento, está na área de serviços domésticos.

A taxa de desocupação e desemprego, bem como uma baixíssima média mensal de rendimento, são evidências do empobrecimento da classe trabalhadora no Brasil e reflexo de políticas de desregulamentação da tutela dos direitos dos trabalhadores, a exemplo do que foi mencionado na seção anterior. Mas não é somente isto. Há também uma forte migração do emprego formal para a informalidade, agravando a situação de vulnerabilidade da classe trabalhadora brasileira.

Em levantamento realizado pelo Departamento Intersindical de Estatística e Estudos Socioeconômicos (DIEESE, 2020), constatou-se um saldo negativo do emprego formal no Brasil entre janeiro e maio deste mesmo ano de 1.144.875 milhões de empregos, conforme demonstra a tabela abaixo:

\begin{tabular}{|c|c|c|c|}
\hline \multicolumn{4}{|c|}{ Saldo do emprego formal por setor econômico - Brasil - Jan a Maio - 2020} \\
\hline \multirow[t]{2}{*}{ Atividades Econômicas } & Acumulado no ano com ajuste & & \\
\hline & Admissões & Desligamentos & Saldo \\
\hline Total & 5.766 .174 & 6.911 .049 & -1.144 .875 \\
\hline $\begin{array}{l}\text { Agricultura, } \\
\text { produção florestal, pescuária, } \\
\text { aquicultura }\end{array}$ & 348.848 & 323.418 & 25.430 \\
\hline Indústria geral & 944.118 & 1.180 .528 & -236.410 \\
\hline Construção & 573.732 & 618.379 & -44.647 \\
\hline $\begin{array}{lcr}\text { Comércio, } & \text { reparação } & \text { de } \\
\text { veículos automotores } & \text { e } \\
\text { motocicletas } & & \\
\end{array}$ & 1.260 .999 & 1.707 .583 & -446.584 \\
\hline Serviços & 2.638 .477 & 3.081 .057 & -442.580 \\
\hline Não identificado & 0 & 84 & -84 \\
\hline
\end{tabular}

Fonte: DIEESE/CAGED-Ministério da Economia 
Identifica-se que o maior número de desligamentos ocorreu nos setores de comércio, de reparação de veículos automotores e de motocicletas, seguidos do setor de serviços. Esses dois nichos representam quase 900 milhões de desempregados. É importante fazer o cotejo entre esses dados e os dados sobre a renda média em cada setor, acima exposta, para considerar que, no setor de comércio e no de serviços, a renda mensal não alcança a quantia de $\mathrm{R} \$ 2.000,00$, ou seja, é voltada para o atendimento de necessidades básicas da população, como alimentação, educação, transporte e saúde.

A perda do emprego e a permanente necessidade de suprir as necessidades básicas repercute no aumento desenfreado da informalidade. Em todo o País, segundo o Dieese (2020) o índice de informalidade é de 39,9\%. Ainda assim, para cada trabalhador com carteira assinada que ficou desempregado, dois informais ficaram sem trabalhar entre o trimestre encerrado em fevereiro e os três meses até maio, devido à queda das atividades econômicas e à redução no número de pessoas nas ruas, que ocasionou a diminuição das vendas desses trabalhadores no mercado informal. Também no ano de 2020, o Brasil alcançou níveis elevados de requerimentos de concessão do benefício do seguro-desemprego, como revelam os dados de pesquisa realizada pelo DIEESE (2020):

Número de pedidos de Seguro-Desemprego - Todos os setores Brasil - Jan/2019 a Maio/2020

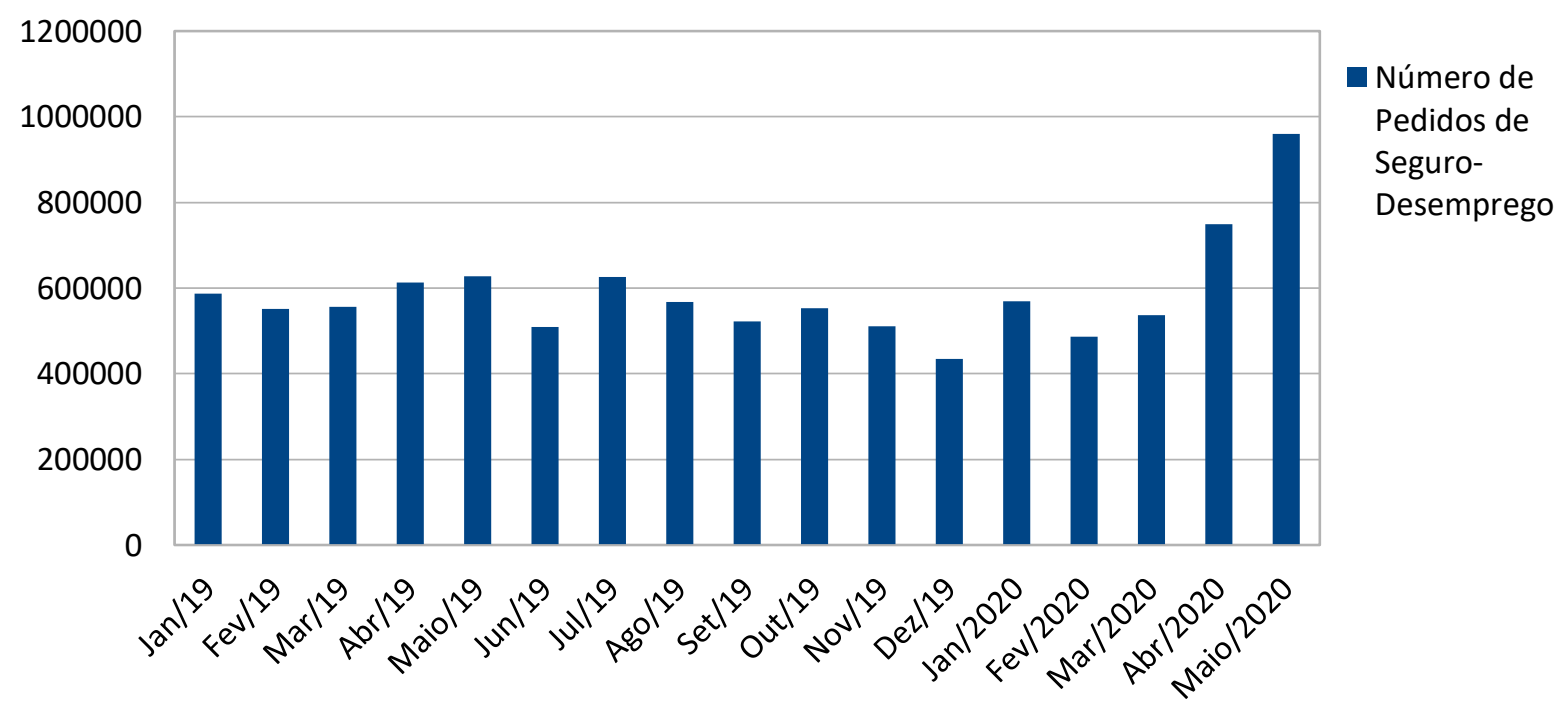


O mês de maio de 2020 reflete um aumento expressivo no requerimento de concessão do benefício no País, alcançando, somente no mês de maio/2020, 960.258 pedidos, o que, em comparação ao mesmo mês do ano anterior (627.779), corresponde a um aumento de aproximadamente, $30 \%$ em relação ao ano atual.

Sobre este ponto, interessa observa que os trabalhadores informais não têm acesso ao seguro-desemprego. Assim, a despeito do aumento de pedido para pagamento de tal benefício, isto decorreu da dispensa de empregados devidamente formalizados, com registro do vínculo empregatício. Assim, ainda há um grande contingente de pessoas sem renda que estão fora do alcance do benefício citado.

É certo que, no Brasil, o nível de desemprego já estava alto, o que foi agravado pela pandemia do COVID-19. Neste aspecto, Hecksher (2020, p. 7) assinala que “de fevereiro a julho de 2020, já se acumularam cinco meses consecutivos de encolhimento do mercado de trabalho brasileiro nas estatísticas públicas”. Por ser recente, não há estudos ou projeções sobre o cenário do emprego brasileiro em caso de não edição das medidas pelo governo para fins de comparação com o cenário visto acima.

Por outro lado, pretende-se demonstrar, com este estudo, que as medidas adotadas não surtiram o objetivo propalado nas suas exposições de motivos, as quais, em regra, previam a manutenção do emprego e a garantia da renda. O impacto, conforme visto nos gráficos acima, foi o aumento do desemprego, o que pode ser corroborado pela quantidade de pedidos de recebimento do seguro-desemprego, vez que tal benefício é concedido ao empregado devidamente formalizado, que atenda a diversos critérios, dentre os quais o tempo contratual.

As medidas não conduziram à manutenção do emprego. Ao contrário, permitiram a precarização das relações trabalhistas, em decorrência da ampla liberdade concedida ao empregador para pactuar situações laborais em prejuízo ao empregado.

A análise dos microdados da Pesquisa Nacional por Amostra de Domicílios (PNAD) Covid-19 (IBGE, 2020) revela que os 
trabalhadores por conta própria receberam, efetivamente, apenas $63,4 \%$ do que habitualmente recebiam, tendo seus rendimentos efetivos médios alcançado apenas R \$1.164,00. Já os trabalhadores do setor privado sem carteira assinada receberam efetivamente $79,1 \%$ do habitual. Por sua vez, trabalhadores do setor privado com carteira e funcionários públicos receberam efetivamente, em média, acima de 90\% do habitual.

Além disso, os microdados da PNAD Covid-19 de junho (IBGE, 2020) permitem avaliar que o auxílio emergencial foi suficiente para compensar $84 \%$ da perda da massa salarial entre os que permaneceram ocupados, sendo um instrumento importante na compensação da renda suprimida em virtude da pandemia, principalmente nos domicílios de baixa renda. Contudo, com bem assinala Carvalho (2020), as diferenças permaneceram expressivas, e ainda muito fortes para os trabalhadores informais, tendo inclusive aumentado entre os domicílios de renda muito baixa.

Nesse cenário, surge a necessidade de definição de uma estratégia de financiamento do setor público capaz de manter a execução das medidas de política fiscal - notadamente as orientadas ao financiamento das políticas de saúde e de assistência social, de sustentação do nível de emprego e renda e de suporte aos entes federativos subnacionais - e a gestão sustentável da dívida pública em uma perspectiva de longo prazo, capaz de articular as medidas extraordinárias de curto prazo com a agenda de longo prazo, relacionada às condições de retomada e de sustentação do crescimento econômico (SILVA, M., 2020, p. 48), assertiva que se revela correta.

Por outro lado, conforme examinado na subseção 3.5, o Governo Federal já iniciou a retirada do investimento e do repasse de verbas destinadas à manutenção de renda e assistência social. Tal conduta permite compreender que, a despeito da instituição de um instrumento de política social (auxílio emergencial), a atuação governamental continua sendo dirigida pela ótica neoliberal, conquanto não há preocupação com a garantia mínima de subsistência do trabalhador, considerando que o valor atual do citado auxílio 
representa menos de um terço do salário mínimo vigente, o qual, para todo os efeitos, é reputado como o mínimo para a satisfação das necessidades básicas do indivíduo.

A flexibilização das relações de trabalho e, com ela, das jornadas de trabalho, aponta Basso (2018), equivale à desregulamentação, ao rompimento das velhas regras do compromisso social conflitivo que se estabeleceu entre capital e trabalho no pós-guerra para substituí-las por novas regras, mais distantes e contrárias à velha práxis de concertação ou cogestão, ditadas pelas empresas. Aumentam, em todos os lugares, o trabalho por turno, o trabalho noturno, o trabalho aos sábados e aos domingos, e ainda, a prestação de horas extras.

Quetes, Ferraz e Villatore (2019, p. 172) observam que, embora as relações de trabalho e emprego apresentem novas formas, em decorrência do fenômeno de globalização e as condições clássicas de vínculo de emprego precisem ser revistas, é imperiosa a luta contra a flexibilização desenfreada e contra a desregulamentação, que constituem afrontas aos direitos sociais dos trabalhadores.

É a intensificação clara do precariado, do flexível e o agravamento de desigualdades e, consequentemente, das diversas vulnerabilidades já inerentes ao mundo da classe trabalhadora.

O precariado, segundo Standing (2019, p. 23), poderia ser descrito como um neologismo que combina o adjetivo "precário" e o substantivo relacionado "proletariado". É uma classe em formação, se não ainda uma classe-para-si. Pode ser visto em termos de processos, na forma pela qual as pessoas são "precarizadas”, sujeitas a pressões e experiências que levam a uma existência precária, de viver no presente, sem uma identidade segura ou um senso de desenvolvimento alcançado por meio do trabalho e do estilo de vida.

O precariado, segundo este autor (2019, p. 23), sente-se frustrado não só por causa de toda uma vida de acenos de empregos temporários, com todas as inseguranças que vêm com eles, mas também porque esses empregos não envolvem nenhuma construção de relações de confiança desenvolvidas em estruturas ou redes 
significadas. Esse trabalhador também não tem nenhum meio de mobilidade para ascender, o que o deixa em suspenso entre a profunda autoexploração e o desengajamento.

Submetidos a essas modalidades de trabalho, com contratos "zerados”, “uberizados”, “pejotizados”, "intermitentes”, "flexíveis”, os trabalhadores ainda são obrigados a cumprir metas, impostas frequentemente por práticas de assédio capazes de gerar adoecimentos, depressões e suicídios (ANTUNES, 2020a). Nesse sentido, assim como o capital é um sistema global, o mundo do trabalho e seus desafios são também cada vez mais transnacionais, em um processo de re-territorialização e também de desterritorialização (ANTUNES, 2009).

Mas esse é um reflexo já sabido das políticas neoliberais que, durante crises, como a da atual pandemia do coronavírus, também estão alterando as jornadas de trabalho. Um sistema que está em plena consonância com a imperante tendência à desregulamentação das relações de trabalho (BASSO, 2018), ou ainda, que, paulatinamente, anuncia a substituição da mão de obra e a apropriação do trabalho, por máquinas, algoritmos, robôs e tudo o que não torna (ou menos) oneroso o desenvolvimento das atividades do agente econômico empregador.

Antunes (2020b) sintetiza a situação atual pela expressão capital pandêmico, associando a crise estrutural do capital que já vínhamos experimentando com o que chama de sistema de metabolismo antissocial do capital, destacando o seu claro caráter discriminatório em relação às classe sociais, sem olvidar a divisão sociossexual e racial do trabalho, os trabalhadores indígenas, os imigrantes e os refugiados.

Identifica-se, a partir do marco legislativo, que não houve preocupação com os mais vulneráveis, acima identificadas. A regulamentação ocorreu, especialmente, para aqueles que mantêm vínculos de empregos formais, regidos pela CLT. Para tais relações, a produção normativa foi vasta, especialmente em decorrência do objetivo de assegurar, ao empregador, proteção jurídica e redução de 
O Mundo Do Trabalho Em Tempos De Pandemia No Brasil: 0 Incremento Da...

despesas. O reflexo disso é a quantidade de pessoas desempregadas e o aumento do número de solicitações de habilitação para o recebimento de seguro-desemprego, dentre outros fatores acima demonstrados.

Por outro lado, observa-se que não houve nenhuma política efetiva voltada a garantir o trabalho e a manutenção de renda dos trabalhadores informais, deixando-os ao largo da proteção social estatal.

\section{CONSIDERAÇÕES FINAIS}

$\mathrm{O}$ trabalho humano não pode ser pensado como um acessório da empresa ou do empregador, adaptando-se a tudo de forma flexível, precarizada ou desumanizada. É preciso repensar a forma de apropriação do trabalho, ressignificá-lo, para assim, concebê-lo como instrumento de dignidade, desenvolvimento e garantia da racionalização e satisfação básicas do cidadão.

Com aquiescência expressa ao que externaliza Piketty (2014), tem-se que a evolução dinâmica de uma economia de mercado e de propriedade privada, deixada à sua própria sorte, contém forças de convergência importantes, ligadas sobretudo à difusão do conhecimento e das qualificações, mas também forças de divergências vigorosas e potencialmente ameaçadoras para as nossas sociedades democráticas e para os valores de justiça social sobre os quais elas se fundam. Portanto, regular o capital no século XXI não é uma alternativa, é uma necessidade de mitigação dos efeitos deletérios das políticas neoliberais recentes da extrema direita.

Entende-se que o Estado, dentro do papel que lhe foi reservado pela Constituição Federal, tem o dever de assegurar plena realização dos direitos sociais, dentre eles, o trabalho digno. Contudo, diante de um contexto de crise, seja econômica ou sanitária, observa-se que o 
primeiro alvo de corte financeiro ou reestruturação é a área relativa à proteção social, atingindo-se direitos resultantes de árdua luta histórica para a sua implementação.

O processo de conquista e de efetivação dos direitos sociais prolonga-se por anos. Por outro lado, mostra-se que, no Brasil, basta a edição de uma medida provisória para excluir, mitigar ou afastar esses direitos, o que é bastante dissonante da exigência fática, pois é exatamente nos momentos de crise que as pessoas mais vulneráveis necessitam de proteção, o que não é observado pelos diplomas examinados.

Especificamente sobre o direito do trabalho e os direitos dos trabalhadores, entende-se que estão relacionados à própria existência do direito de liberdade e de cidadania dos indivíduos, pois é por meio deles que os trabalhadores garantem os demais direitos sociais. $\mathrm{O}$ trabalho e a sua proteção representam instrumentos de promoção de civilização e cidadania, sem as quais impera a exploração sem limites, para a extração progressiva da mais-valia.

Como dito, cabe ao Estado a promoção do direito ao trabalho, dentro do ideal de formulação de políticas públicas voltadas à garantia do pleno emprego, de renda justa e de proteção previdenciária. No entanto, o que se observa é um "mercado" de produtos legislativos que visam a golpear as raízes estruturantes do trabalho e de seu valor, que estão, a todo momento, sendo alvo de ataques advindos do mercado a partir da escolha de agendas legislativas precarizantes baseadas no ideal neoliberal.

De fato, o Direito do Trabalho deve se ocupar da compreensão de sua alteração morfológica para abrigar outras relações que não apenas aquelas circunscritas ao ideário de vínculo empregatício. Contudo, esse reexame não pode acarretar a perda ou a diminuição daquilo que já foi conquistado.

As políticas devem contribuir para o desenvolvimento do país como um todo, no âmbito econômico, mas, também e, principalmente, no tocante à preservação da vida, da saúde, do pleno emprego, da segurança alimentar e do bem-estar das pessoas, evitando a existência 
de privações de liberdade, sem a qual o indivíduo fica desprovido de exercer todas as suas faculdades e capacidades.

A partir do exame da primeira seção foi possível identificar a subordinação do Estado ao capital, com a implementação de agendas neoliberais, em clara desconstrução dos direitos sociais. Em tempos de crise, com a pandemia decorrente do COVID-19, o Estado responde de forma consentânea com essa subjugação.

O exame dos marcos normativos demonstra que a regulação da relação laboral ocorreu a partir do viés do empresariado, com alteração profunda das bases estruturantes do Direito do Trabalho.

A "legislação de crise", como conhecida, aprofundou a precarização das relações laborais, reduziu salário e jornada, e permitiu a total regulação das relações por acordo individual entre partes que não gozam de igualdade material. Essa pseudo negociação acarreta a precarização e a violação dos direitos do trabalhador, que não tem condições materiais e substanciais de se contrapor aos interesses do capital.

Por essas premissas, voltando à pergunta que norteou este estudo, pode-se afirmar que as medidas legislativas adotadas pelo governo brasileiro não têm sido eficazes para combater o desemprego e a precarização do trabalho durante a pandemia do COVID-19. Conforme os dados oficiais relativos ao mercado de trabalho, o Brasil experimenta um nível de desemprego, de redução de renda e de aumento de desigualdade social nunca antes visto. O marco regulatório no Brasil foi eficiente para garantir segurança às empresas, mas não o foi para assegurar a observância dos direitos sociais.

Em relação aos trabalhadores informais, identificou-se que a concessão de auxílio emergencial, a despeito de permitir o incremento de renda em lares que nada possuíam, deu-se em valor extremamente reduzido para a aquisição do mínimo necessário para uma vida digna. Neste ponto, a estratégia governamental deixa claro o seu direcionamento pelo ideal neoliberal, sem preocupação com os trabalhadores precarizados, reduzindo-se o papel do Estado como 
provedor e assegurador de proteção social aos mais necessitados.

Reconhece-se que ainda é cedo para alcançar todas as consequências decorrentes da pandemia e dos marcos regulatórios no mercado de trabalho. Todavia, as medidas adotadas e os dados identificados sinalizam o aumento da precarização dos direitos do trabalhador, sendo necessária e urgente a correção do rumo a fim de evitar que o ser humano seja reduzido a um mero instrumento a serviço do capital.

Data de Submissão: 31/07/2020

Data de Aprovação: 14/09/2020

Processo de Avaliação: double blind peer review

Editor Geral: Jailton Macena de Araújo

Editor de Área: Fernando Joaquim Ferreira Maia

Assistente Editorial: Samara Taiana de Lima Silva

\section{REFERÊNCIAS}

ANTUNES, Ricardo. Coronavírus: o trabalho sob fogo cruzado. São Paulo: Boitempo, 2020.

ANTUNES, Ricardo. O Privilégio da Servidão: o novo proletariado de serviços na era digital. 2. ed. rev. amp. São Paulo: Boitempo, 2020.

ANTUNES, Ricardo. Os Sentidos do Trabalho: ensaio sobre a afirmação e negação do trabalho. São Paulo: Boitempo, 2009.

BALMANT EMERIQUE, Lilian Márcia. Direitos Sociais no

Brasil: balanço de uma jornada com destino incerto. Revista Justiça 
O Mundo Do Trabalho Em Tempos De Pandemia No Brasil: 0 Incremento Da...

do Direito, v. 34, n. 1, p. 76-105, 30 abr. 2020. Disponível em: http://seer.upf.br/index.php/rjd/article/view/10979. Acesso em 31 jul. 2020.

BASSO, Pietro. Tempos Modernos, Jornadas Antigas: vidas de trabalho no início do século XXI. São Paulo: Unicamp, 2018.

BRASIL. [Constituição (1988)]. Constituição da República

Federativa do Brasil. Brasília, DF: Presidência da República. Disponível em:

http://www.planalto.gov.br/ccivil_03/constituicao/constituicaocom pilado.htm. Acesso em: 20 jul. 2020.

BRASIL. Decreto Legislativo no 6, de 20 de março de 2020. Reconhece, para os fins do art. 65 da Lei Complementar $n^{\circ} 101$, de 4 de maio de 2000, a ocorrência do estado de calamidade pública [...]. DF: Congresso Nacional. Disponível em:

http://www.planalto.gov.br/ccivil_03/portaria/DLG6-2020.htm. Acesso em 12 set. 2020.

BRASIL. Decreto no 10.412, de 30 de junho de 2o2o. Altera o Decreto $\mathrm{n}^{\mathrm{O}} 10.316$, de 7 de abril de 2020, para prorrogar o período de pagamento do auxílio emergencial de que trata a Lei $\mathrm{n}^{0} 13.982$, de 2 abril de 2020. Brasília, DF: Presidência da República. Disponível em: http://www.planalto.gov.br/ccivil_03/_ato2019-

2022/2020/decreto/D10412.htm. Acesso em 12 set. 2020.

BRASIL. Decreto-Lei $n^{\circ} 5 \cdot 45^{2}$, de $1^{\circ}$ de maio de 1943. Aprova a Consolidação das Leis do Trabalho. Rio de Janeiro, RJ: Presidência da República. Disponível em:

http://www.planalto.gov.br/ccivil_o3/decreto-lei/del5452.htm.

Acesso em: 18 jan. 2020.

BRASIL. Exposição de Motivos EM no ooo81/2020 ME, de 22 de março de 2020. Exposição de Motivos da Medida Provisória ${ }^{0}$ 927, de 22 de março de 2020. Brasília, DF: Ministério da Economia. Disponível em: http://www.planalto.gov.br/ccivil_03/_Ato20192022/2020/Exm/Exm-MP-927-20.pdf. Acesso em 28 ju. 2020.

BRASIL. Exposição de Motivos no ooo11/2020 MINFRA, de 21 de Março de 2020 Exposição de motivos da Medida Provisória n. 945, de 4 de abril de 2020. Brasília, DF: Ministério da Infraestrutura. Disponível em:http://www.planalto.gov.br/ccivil_03/_Ato20192022/2020/Exm/Exm-MP-945-20.pdf. Acesso em 12 set. 2020.

BRASIL. Exposição de Motivos no oo104/2020 ME, de $1^{\circ}$ de abril de 2020. Exposição de Motivos da Medida Provisória no ${ }^{0}$ 936, de 1 de abril de 2020. Brasília, DF: Ministério da Economia. Disponível em: http://www.planalto.gov.br/ccivil_03/_Ato20192022/2020/Exm/Exm-MP-936-20.pdf.Acesso em 28 jul. 2020. 
BRASIL. Lei no 13.467, de 13 de julho de 2017. Altera a Consolidação das Leis do Trabalho (CLT) [...]. Brasília, DF: Presidência da República. Disponível em: http://www.planalto.gov.br/ccivil_03/_Ato20152018/2017/Lei/L13467.htm. Acesso em 12 set. 2020.

BRASIL. Lei no 13.982, de 2 de abril de 2020. [...] estabelece medidas excepcionais de proteção social a serem adotadas durante o período de enfrentamento da emergência de saúde pública de importância internacional decorrente do coronavírus (Covid-19) responsável pelo surto de 2019, a que se refere a Lei no 13.979 , de 6 de fevereiro de 2020. Brasília, DF: Presidência da República. Disponível em: http://www.planalto.gov.br/ccivil_03/_ato20192022/2020/Lei/L13982.htm. Acesso em 12 set. 2020.

BRASIL. Medida Provisória n. 1.ooo, de 2 de setembro de 2020. Brasília, DF: Presidência da República. Disponível em: http://www.planalto.gov.br/CCIVIL_03/_Ato20192022/2020/Mpv/mpv100o.htm Acesso em 12 set. 2020.

BRASIL. Medida Provisória n. 928, de 23 de março de 2020. Altera a Lei $\mathrm{n}^{0} 13.979$, de 6 de fevereiro de 2020, que dispõe sobre as medidas para enfrentamento da emergência de saúde pública de importância nacional decorrente do coronavírus responsável pelo surto de 2019, e revoga o art. 18 da Medida Provisória no 927, de 22 de março de 2020. Brasília, DF: Presidência da República. Disponível em: http://www.planalto.gov.br/ccivil_03/_ato20192022/2020/Mpv/mpv928.htm. Acesso em 12 set. 2020.

BRASIL. Medida Provisória n. 936, de 1 de abril de 2020. Institui o Plano Emergencial de Manutenção do Emprego e da Renda e dispõe sobre medidas trabalhistas complementares par enfrentamento do estado de calamidade pública [...]. Brasília, DF:

Presidência da República. Disponível em:

http://www.planalto.gov.br/ccivil 03/ Ato2019-

2022/2020/Mpv/mpv936.htm. Acesso em: 12 set. 2020.

BRASIL. Medida Provisória n. 945, de 4 de abril de 2020. Dispõe sobre as medidas temporárias em resposta à pandemia decorrente da covid-19 no âmbito do setor portuário [...]. Brasília, DF: Presidência da República. Disponível em:

http://www.planalto.gov.br/ccivil_03/_Ato20192022/2020/Mpv/mpv945.htm. Acesso em 12 set. 2020.

BRASIL. Medida Provisória no 927, de 22 de março de 2020. Dispõe sobre as medidas trabalhistas para enfrentamento do estado de calamidade pública [...]. Brasília, DF: Presidência da República. Disponível em: http://www.planalto.gov.br/ccivil_03/_Ato20192022/2020/Mpv/mpv927.htm. Acesso em 12 set. 2020.

BRASIL. Portaria no 16.655, de 14 de julho de 2020. Disciplina 
O Mundo Do Trabalho Em Tempos De Pandemia No Brasil: 0 Incremento Da...

hipótese de recontratação nos casos de rescisão sem justa causa, durante o estado de calamidade pública de que trata o Decreto Legislativo $n^{0}$ 6, de 20 de março de 2020. Brasília, DF: Ministério da Economia/Secretaria Especial de Previdência e Trabalho. Disponível em: http://www.planalto.gov.br/ccivil_03/Portaria/PRT/Portaria16655-20-ME.htm. Acesso em 28 jul. 2020.

BRASIL. Supremo Tribunal Federal. Ação Direta de

Inconstitucionalidade n⿳0 ${ }^{\circ}$ 6380. Decisão liminar para suspender a eficácia do artigo 29 da Medida Provisória 927/2020. Redator para o acórdão Ministro Alexandre de Moraes, Sessão Virtual de 8.5.2020 a 14.5.2020. Disponível em:

http://portal.stf.jus.br/processos/detalhe.asp?incidente $=5890866$. Acesso em 28 jul. 2020.

BRASIL. Supremo Tribunal Federal. Ação Direta de Inconstitucionalidade $\mathbf{n}^{\mathbf{0}} \mathbf{6 3 4 2}$. Nega referendo ao indeferimento da medida cautelar tão somente em relação aos artigos 29 e 31 da Medida Provisória 927/2020 e, nos termos do voto do Ministro Alexandre de Moraes, Redator para o acórdão, suspendeu a eficácia desses artigos. Redator para o acórdão Ministro Alexandre de Moraes, Sessão Virtual de 29.04.2020. Disponível em:

http://portal.stf.jus.br/processos/detalhe.asp?incidente $=5880968$. Acesso em 28 jul. 2020.

CARVALHO, Sandro Sacchet de. Os efeitos da pandemia sobre os rendimentos do trabalho e o impacto do auxílio emergencial: os resultados dos microdados da PNAD Covid-19 de junho. Carta de Conjuntura, número $48-3^{\circ}$ Trimestre de 2020. Instituto de Pesquisa Econômica Aplicada. Divulgado em 24 de jul. 2020. Disponível em:

https://www.ipea.gov.br/portal/images/stories/PDFs/conjuntura/2 o0724_cc48_mt_final.pdf. cesso em 12 set. 2020.

DELGADO, Mauricio Godinho. Curso de Direito do Trabalho. 19. ed. São Paulo: LTr, 2020.

DEPARTAMENTO INTERSINDICAL DE ESTATÍSTICA E ESTUDOS SOCIOECONÔMICOS (DIEESE). A COVID-19 e os

trabalhadores do comércio. Estudos e Pesquisas n. $94-7$ de Julho 2020. Disponível em:

https://www.dieese.org.br/estudosepesquisas/2020/estPesq94Covid Comercio.pdf. Acesso em: 06 jul. 2020.

DUPAS, Gilberto. A lógica econômica global e a revisão do Welfare State: a urgência de um novo pacto. In: Revista Estudos

Avançados, v. 12, n. 33, p. 171-183, Mai- Aug. 1998. Disponível em: http://www.scielo.br/scielo.php?script=sci_arttext\&pid=So10340141998000200013\&lng=en\&nrm=iso. Acesso em: 12 abr. 2020.

FARIA, José Eduardo. Democracia e governabilidade: os direitos 
humanos à luz da globalização econômica. In: FARIA, José Eduardo (Org.) Direito e globalização econômica; implicações e perspectivas. 3. ed. São Paulo: Malheiros, 2010, pp. 127-160.

FERRER, Walkiria Martinez Heinrich; ALVES, Giovanni.

Flexibilização Trabalhista e o Empresariado Brasileiro: alguns apontamentos. Prim@ Facie, v. 17, n. 35, p. 01-32, 25 set. 2018. Disponível em:

https://periodicos.ufpb.br/ojs2/index.php/primafacie/article/view/ 39470. Acesso em 12 set. 2020.

GARCIA, Ivan Simões; MOREIRA, Eduardo Ribeiro. A Categoria Trabalho em Lukács segundo a Dialética Marxista . Revista Direito e Práxis, [S.l.], v. 11, n. 2, p. 854-879, jun. 2020. ISSN 21798966. Disponível em: https://www.epublicacoes.uerj.br/index.php/revistaceaju/article/view/47652/320 49. Acesso em: 31 jul. 2020.

HECKSHER, Marcos. Cinco meses de perda de empregos e simulação de um incentivo a contratações. Nota Ténica $\mathrm{n}^{0} 87$. Instituto de Pesquisa Econômica Aplicada: agosto de 2020.

Disponível em:

https://www.ipea.gov.br/portal/images/stories/PDFs/nota_tecnica/ 200828_nt_disoc_n_87.pdf. Acesso em 12 set. 2020.

HOBSBAWM, Eric. A era dos extremos: o breve século XX (19141991). São Paulo: Abril, 1995.

INSTITUTO BRASILEIRO DE GEOGRAFIA E ESTATÍSTICA (IBGE). Pesquisa Nacional por Amostra de Domicílios Contínua (PNAD Contínua Junho/2020). Disponível em: https://www.ibge.gov.br/estatisticas/sociais/populacao/9171pesquisa-nacional-por-amostra-de-domicilios-continuamensal.html?=\&t=destaques. Acesso em 09 jul. 2020.

INSTITUTO DE PESQUISA ECONÔMICA APLICADA (IPEA). Cadernos ODS 10: Reduzir as desigualdades dentro dos países e entre eles. Brasília: IPEA, 2019. Disponível em: https://www.ipea.gov.br/. Acesso em: 12 jul. 2020.

MARTÍNEZ LAZCANO, Alfonso Jaime. Los derechos humanos en el estado social y democrático. Revista Eletrônica do Curso de Direito da UFSM, v. 15, n. 2/2020. Disponível em: https://periodicos.ufsm.br/revistadireito/article/view/48166/pdf. Acesso em 31 jul. 2020.

PEREIRA, Mozart Silvano. Trabalho, classe e capitalismo: sobre a interpretação de Marx por Postone. Revista Direito e Práxis, [S.l.], v. 11, n. 2, p. 997-1028, jun. 2020. Disponível em: https://www.epublicacoes.uerj.br/index.php/revistaceaju/article/view/36759. Acesso em: 31 jul. 2020. 
O Mundo Do Trabalho Em Tempos De Pandemia No Brasil: 0 Incremento Da...

PIKETTY, Thomas. O Capital no Século XXI. Rio de Janeiro: Intrínseca, 2014.

POLANYI, Karl. A Grande Transformação; As origens de nossa época. Tradução por Fanny Wrobel. 2. ed. Rio de Janeiro: Elsevier, 2012.

POSTONE, Moishe. Tempo, trabalho e dominação social: uma reinterpretação da teoria crítica de Marx. São Paulo: Boitempo, 2014.

PRONI, Marcelo Weishaupt. História do capitalismo: uma visão panorâmica. Cadernos do CESIT, Campinas, n. 25, out. 1997. Disponível em:

http://www.cesit.net.br/cesit/images/stories/25CadernosdoCESIT.p df. Acesso em 29.07.2020.

QUETES, Regeane Bransin; FERRAZ, Miriam Olivia Knopik; VILLATORES, Marco Antônio César. Direito ao Trabalho como elemento do mínimo existencial, mínimo existencial como limite ao retrocesso social: sacrifícios de direitos dos trabalhadores em tempos de crise e a violação ao princípio da proibição do retrocesso social. Revista do Programa de PósGraduação em Direito - UFC, v. 39, n. 2 (2019): NOMOS 2019.2. Disponível em:

http://www.periodicos.ufc.br/nomos/article/view/31462. Acesso em 31 jul. 2020.

SILVA, Mauro Santos. Política econômica emergencial orientada para a redução dos impactos da pandemia da COVID-19 no Brasil: medidas fiscais, de provisão de liquidez e de liberação de capital. Brasília: Instituto de Pesquisa Econômica Aplicada, julho de 2020. Disponível em:

https://www.ipea.gov.br/portal/images/stories/PDFs/TDs/td_2576. pdf. Acesso em 12 set. 2020.

SILVA, Sayonara Grillo Coutinho Leonardo da. Direito do Trabalho de Crise e a Regulação Laboral da Calamidade. In: MENDES, Felipe Prata; TUPINAMBÁ, Pedro Tourinho; FERREIRA, Vanessa Rocha. Direitos Sociais em Tempos de Crise. São Paulo: Linotec Produção Editorial, 2020.

SILVA, Sayonara Grillo Coutinho Leonardo da. O Brasil das Reformas Trabalhistas: insegurança, instabilidade e precariedade. In: SILVA, Sayonara Grillo Coutinho Leonardo da; EMERIQUE, Lilian Balmant; BARISON, Thiago. Reformas institucionais de austeridade, democracia e relações de trabalho. São Paulo: Ltr, 2018.

STANDING, Guy. O Precariado: A nova classe perigosa. Belo Horizonte: Autêntica, 2019. 
VALENTE, Nara Luiza; FOGAÇA, Vitor Hugo Bueno; SILVA, Silmara Carneiro e. A Reforma Trabalhista Brasileira E Retrocessos Na Garantia De Direitos Fundamentais Do Trabalhador. Prim@ Facie, v. 17, n. 35, p. 01-32, 25 set. 2018. Disponível em: https://periodicos.ufpb.br/index.php/primafacie/article/view/38814 Acesso em 12 set. 2020.

WOOD, Ellen Meiksins. O Império do Capital. São Paulo: Boitempo, 2014. 


\title{
The World Of Work During The Pandemic In Brazil: The Increase Of Precariousness Labor Force
}

\author{
Otávio Bruno da Silva Ferreira
}

\section{Suzy Elizabeth Cavalcante Koury}

\author{
Felipe Guimarães de Oliveira
}

\begin{abstract}
The coronavirus pandemic caused several and deep changes in the world of work. The research aims to discuss whether the legislative measures adopted by the Brazilian government have been effective in the fight against unemployment and job insecurity during the pandemic. It was pointed out as its general objective to identify if the legislative measures are successful in reducing unemployment. In order to do so, we analyzed the implementation of neoliberalism in the world of work and its consequences, and the most important legislative diplomas issued during the pandemic. It was verified, from the examination of official data, that the regulation of employment is in line with the bias of the business community, deepening the precariousness of labor relations, and revealing itself as not efficient to combat unemployment during the pandemic. Methodologically, the research is qualitative, exploratory, with bibliographic and documentary survey.It is divided into sections that presented a brief overview of the influence of capitalism in the world of labor, the emergence of new legislative and regulatory frameworks and the reflections of advances in neoliberal policies and, to finish, an analysis of its consequences in the destruction of the labor protection laws, resulting in unemployment, flexibility, precariousness and substitution of human capital for technological capital.
\end{abstract}

Keywords: COVID-19; Flexibilization; Legislative Measures; Neoliberalism; Unemployment.

DOI: https://doi.org/10.22478/ufpb.1678-2593.2020v19n42.54286

Conteúdo sob licença Creative Commons: Attribuition-NonCommercial-NoDerivative 4.o International (CC BY-NC-ND 4.0) 